\title{
Pliocene and Pleistocene stratigraphic evolution of the western Niger Delta intraslope basins: A record of glacio- eustatic sea-level and basin tectonic forcings
}

Chima Kelvin Ikenna 1, 2, ", Gorini Christian ${ }^{1}$, Rabineau Marina ${ }^{3}$, Granjeon Didier ${ }^{4}$, Do Couto Damien ${ }^{1}$, Leroux Estelle ${ }^{5}$, Hoggmascall Nick ${ }^{6}$

${ }^{1}$ Sorbonne Université-ISTeP UMR 7193, F7500 Paris, France

${ }_{2}^{2}$ Alex Ekwueme Federal University, Ndufu-Alike Ikwo, Ebonyi State, Nigeria

${ }^{3}$ CNRS, UMR 6538, LGO (CNRS/UBO/UBS), Plouzane, France

${ }^{4}$ IFPEN, Rueil-Malmaison, France

5 IFREMER, ZI Pointe du Diable, Plouzane,, France

${ }^{6}$ Shell International, London, UK

* Corresponding author : Kelvin Ikenna Chima, email address : kelvin.chima@sorbonne-universite.fr

\begin{abstract}
:
Although climate proxy $(\delta 180)$ across the world ocean basins reveals that orbital forcing significantly controlled the Pliocene and the Pleistocene sediment deposition, and has been demonstrated in seismic and outcrop studies on the continental shelves of many margins, few or no seismic stratigraphic studies have investigated orbital forcing on deep-water sediment records. In this study, we combined detailed seismic stratigraphy and 3D geomorphological analysis of a high-resolution 3D seismic block in a detailed study of the stratigraphic evolution of the western Niger Delta intraslope basins over the last $5.5 \mathrm{Ma}$. Two mega seismic units named MSU 1 and MSU 2 were identified.
\end{abstract}

The change in sedimentary architecture from (i) mass flows and turbidite sequences to (ii) hemipelagic and turbidite sequences at the MSU 1/MSU 2 transition coincides with a significant $(x 3)$ increase in sedimentation rates and a transition from dominant 400 ka eccentricity cycles (from $5.3 \mathrm{Ma}-0.8 \mathrm{Ma}$ ) to dominant 100 ka eccentricity cycles, at the Middle Pleistocene Transition (MPT) (circa 0.8-0 Ma). The timing of these changes was estimated based on a detailed analysis of seismic facies succession, correlation of seismic markers with high-resolution sea-level and oxygen isotope curves, and estimation of sequence duration. Further changes in the sedimentary record, characterised by turbidite-dominated sequences at the lower part of MSU 1 to mixed mass flows and turbidite sequences at the upper part of MSU 1, were respectively correlated with changes that occurred in the early Pliocene (circa $4.9 \mathrm{Ma}$ ) and in the early Pleistocene (circa 2.6 Ma).

The depositional sequence on the western Niger Delta intraslope basin is usually characterised by a falling stage erosional surface (FSES) at its base and top (sequence boundary), and by (i) basal MTDs/bypass facies (where preserved), (ii) turbidite feeder channels/aggrading or meandering channel levee complexes and/or MTDs (slides/slumps) and (iii) hemipelagic drapes that successively document the falling stage, lowstand to early transgressive and late transgressive to highstand transits of the shoreline. This seismic stratigraphic study demonstrates for the first-time sequence cyclicity associated with orbital 
(Milankovitch) forcing in the deep-water Niger Delta over the last 5.5 Ma. The Pliocene and Pleistocene sedimentary records of the western Niger Delta intraslope basins were controlled by interplay between allocyclic forcing linked to glacio-eustatic sea-level oscillations and basin tectonics associated with mobile shale movements, the latter being more prevalent from the early Pliocene to the MPT.

If calibrated with high-resolution biostratigraphic data in future studies, this study could serve as a useful analogue for further studies in the Gulf of Guinea, equatorial Atlantic and other margins fed by large deltas.

\section{Highlights}

- Seq. cycles linked to the Milankovitch cycles are recorded regionally on the Niger Delta slope. The early Pliocene-mid Pleist. (5.5-0.8 Ma) is dominated by 400 ka eccentricity sequences. $>$ The mid Pleist.present $(0.8-0 \mathrm{Ma})$ is dominated by $100 \mathrm{ka}$ eccentricity sequences. Increase in sedimentation rates at the MPT facilitated the preservation of the $100 \mathrm{ka}$ sequences. Glacio-eustatic and shale tectonic forcings controlled the Pliocene and Pleistocene stratigraphy.

Keywords : Niger Delta, Intraslope basins, Pliocene, Pleistocene, Seismic stratigraphy, Allocyclic forcing, Eccentricity cycles. 


\section{Introduction}

Deep-water sediments are important archives of the Farth's history not only because they record past climatic, geodynamic, environmental and h`a. dynamic changes (e.g. Burbank,1992; Molnar, 2004; Catuneanu, 2006; Posamentier 'id Kolla, 2003; Clift, 2010; Zecchin and Catuneanu, 2010), but also because they l. nst viable hydrocarbon fields (see review in Morley et al., 2011). Understanding the complex interplay between allocyclic (e.g. eustasy, tectonics, climate and indirectly sediment $\cdots n \mathfrak{v}$, and autocyclic (e.g. channel avulsion) or regional forcings (e.g. delta lobe switci ing, shale tectonics etc.), is critical for interpretation of the evolution of deep-water sedinı`riary systems (e.g. Elliot, 1975; Jervey, 1988; Posamentier et al., 1988; Pulham, 1989; L:nselle, 1991; Wiener et al., 2010; Miall, 2010; Morley et al., 2011; Catuneanu and Zecchin, 2013).

The Pliocene and Pleistocene are ideal time intervals for this kind of study because eustasy and climate proxies $\left(\delta^{18} \mathrm{O}\right)$ are well constrained and show significant variations both in amplitude and frequency (e.g. Ruddiman et al., 1989; Imbrie et al., 1993; Bassinot et al., 1994;

a,b* Corresponding autho :: Kelvin Ikenna Chima; Sorbonne Université; Institut des Sciences de la Terre (ISTeP), Case 129, Tour 56/66, fifth floor, 4 Place Jussieu, 75252, Paris Cedex. E-mail; kelvin.chima@sorbonne-universite.fr; kelvini.chima@gmail.com 
Leroy et al., 1999; Shackleton, 2000; Lisiecki and Raymo, 2005; Miller et al., 2005; Gibbard et al., 2010; Gibbard and Lewin, 2016; Raymo et al., 2018). Published climate proxies across the worlds' ocean basins show that the Pliocene and Pleistocene were controlled by orbital forcing (Milankovitch cycles) of three major periods namely: (i) precession (23 ka), (ii) obliquity (41 ka), and (iii) eccentricity (400 ka and $100 \mathrm{ka}$ ) (Lisiecki and Raymo, 2007). The early Pliocene from (5.3 Ma) to the early Pleistocene was dominated by obliquity cycles (41 ka), while the middle Pleistocene (circa 1.4 Ma) to the present was dominated iv eccentricity (400 to 100)

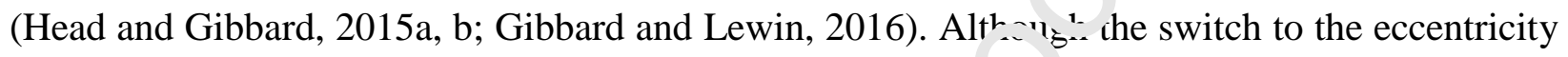
cycles is poorly understood and a transition period from i 4 to 0.4 Ma was suggested by Head and Gibbard (2015a, b), and Gibbard and Lewin (2016), . marked change to increasingly severe glacial cycles, the so-called '0.8 Ma event' ( $\mathrm{i}{ }^{\circ} \mathrm{el} \mathrm{i}$ and Raymo, 2007; Head and Gibbard, 2015a, b) or '0.9 Ma' (Miller et al., 200' - F' derfield et al., 2012), is usually interpreted as the Middle Pleistocene Transition (MPT).

Sedimentary records all ove- th ' vorld show the imprint of tectonic, climatic and glacioeustatic cycles of different ordt. (haq et al., 1987). Fourth-order climate cycles lasting $400 \mathrm{ka}$ have been reported during the D iocene e.g. on the continental shelf offshore Foz do Amazonas Basin (Brazil), with inc: sed valleys, slope canyons and mass wasting (Gorini et al., 2014). During the Pleistocene, fifth-order glacio-eustatic sea-level changes with 100 ka periodicity are also well documented with marked shoreline progradation on the shelf and increased deep-water sedimentation during glacials e.g. in the Mediterranean Sea over the last 500 ka (Rabineau et al.,2006; Ridente et al., 2008; Lafosse et al., 2018). During the Pliocene, sediment architecture in the Mediterranean Sea does not appear to be much imprinted by the 400 ka cycles as shown in seismic (Rabineau et al., 2014) and numerical simulations (Leroux et al., 2014), probably 
because of an anomaly in accommodation created by the erosion of the entire margin after the Messinian Salinity Crisis. 100-ka glacio-eustatic cycles have also been described worldwide e.g. offshore Alaska (Gulick et al., 2012), in the Gulf of Mexico (Galloway, 2001) and the Bengal fan (Werber et al., 1997).

In the eastern Niger Delta, Jermannaud et al. (2010) and Rouby et al. (2011), documented a transition from global climate-controlled sequences from circa 4-2.5 Ma to sediment supplycontrolled sequences from 2.5 Ma to the present. These auth rs . Iso demonstrated a general progradation and an increase in sedimentation rates from $4-<5 \mathrm{~N}$ a, followed by a retrogradation and a decrease in sedimentation rates over the last 2.5 Ma. Additionally, Riboulot et al. (2012), showed that eccentricity forcing of 100 ka periodi $\cdots$ es has controlled the stratigraphic evolution of the eastern Niger Delta continental shelf $r$. r . he last $0.5 \mathrm{Ma}$.

In the western Niger Delta slope, wht॰ the present study was conducted (Fig. 1), Jobe et al. $\left(2015,2016\right.$; red box in Fig. 1A, $\Gamma$ ), $: n^{\prime}$ ked changes in sedimentation rates during the last 130 ka (MIS 5e to the present) to glac: $1 /$ in 2 rglacial cycles with increased sedimentation rates during the lowering of the sea level ( $\mathrm{N}_{i}{ }^{\top} \mathrm{S} 3$ and MIS2) and an overall reduction in sedimentation during a rapid post-glacial se ${ }^{\Upsilon}-\mathrm{lt}$ vel ise associated with the Meltwater pulse 1A at $14 \mathrm{ka}$. Earlier studies e.g. Lézine et al. (200ミ). Weldeab et al. (2011); Collins et al. (2014); Govin et al. (2014) and Armitage et al. (2015), linked the increase in sedimentation rates in the Gulf of Guinea during the Quaternary to the West African Monsoon. A recent high-resolution, 3D seismic and sequence stratigraphic study of the western Niger Delta slope (yellow box in Fig. 1A, C, D, E) by Chima et al. (2019, dated the Neogene stratigraphic record from the Burdigalian (18.5 Ma) to the late Miocene (5.5 Ma), and described interactions between mobile shale and erosional submarine channel over the last 5.5 Ma. However, the lack of biostratigraphic data for the Pliocene and 
Pleistocene poses a challenge to constraining the timing of major changes in sedimentary records.

Despite the above-mentioned studies of the Pliocene and Pleistocene sedimentary records in the Niger Delta, no study has investigated its control by orbital forcings from the late Messinian (5.5 Ma) to the present. Hence, the objective of this paper is to perform a detailed analysis of the stratigraphic evolution of the western Niger Delta intraslope basins over the last 5.5 Ma with a view to (i) proposing a sequence stratigraphic frat. awork for the Pliocene and

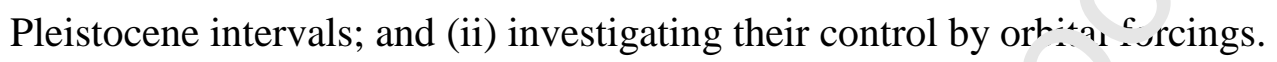

The Niger Delta is an ideal laboratory to study climate stratigraphy and slope depositional processes because it is located on a pu olve margin where the imprints of regional/global climate dynamics, sea-level varia: in gravity-tectonics, drainage evolution and sediment supply are well imaged on high- asc ation 3D seismic reflection data.

\section{Regional Setting}

The Cenozoic Niger 1 elta is located in the Gulf of Guinea on the equatorial Atlantic margin of West Africa (Fin 11 . The delta is the twelfth largest petroleum province in the world (Tuttle et al., 1999). It co ers an area of $\sim 140,000 \mathrm{~km}^{2}$ with a maximum sediment thickness of $\sim$ 12 km (Allen, 1965; Evamy et al., 1978; Doust and Omatsola, 1990). The Niger Delta is divided into the Eastern and the Western lobes by a Cretaceous basement high [the Charcot Fracture Zone (CFZ)] (Corredor et al., 2005; Fig. 1A). The development of the delta since the late Eocene (Fig. 1B, C), has led to three major structural zones:(i) an extensional zone (EZ) below the continental shelf characterised by normal faults; (ii) a translational zone (TZ) below the upper slope dominated by mobile shales and intraslope basins, and (iii) a contractional zone (CZ) 
located at the toe of the slope characterised by reverse faults and detachment folds (Doust and Omatsola, 1990; Damuth, 1994; Cohen and McClay, 1996; Connors et al., 1998; Morgan, 2004; Bilotti et al., 2005; Corredor et al., 2005; Fig. 1A, C).

The classification scheme of Prather et al. (2003) describes the western Niger Delta slope profile as a 'graded slope' characterised by a seafloor whose downslope profile is elevated above the level of theoretical concave-upward, smoothed graded profile. Shale tectonics on the Niger Delta slope give rise to shale/thrust-cored structural hivı flanked by mobile shale withdrawal intraslope basins that interact with sediment-grail, stows (Doust and Omatsola, 1990; Damuth, 1994; Cohen and McClay, 1996; Connor et al., 1998; Graue, 2000; Morgan, 2004; Bilotti et al., 2005; Corredor et al., 2005; Wiener $\epsilon_{\bullet}$ al., 2010; Prather et al., 2012; Fig. 1D, E). The western Niger Delta slope is in cons ${ }^{\dagger} 1^{+} d^{d}$ namic equilibrium as the movements of mobile shale create structural highs whicl in curn, are smoothed by sediment-gravity flows that preferentially accumulate within adjacen. intraslope basins (Deptuck et al., 2003; Adeogba et al., 2005; Bakare et al., 2007; Prather + a. 2012; Clark and Cartwright, 2012; Chima et al., 2019; Fig. 1D, E). The distribution oi shaie/thrust-cored structures on the western Niger Delta slope significantly controls the $m_{\mathrm{O}_{1}}{ }^{n-1}$ ology of submarine channels, depositional patterns, reservoir architecture and distribu: on (e.g. Adeogba et al., 2005; Bakare et al., 2007; Jobe et al., 2015, 2016; Clark and Cartwright, 2012; Deptuck et al., 2012; Prather et al., 2012; Jolly et al., 2016; Hansen et al., 2017; Chima et al., 2019). The present study was conducted in the translational zone of the western Niger Delta slope at the transition between the extensional and the contractional domains (Fig. 1A, C). The study area covers $638 \mathrm{~km}^{2}$ at $\sim 120 \mathrm{~km}$ from the presentday coastline and lies at water depths ranging from 900 to 1,755 m (Fig. 1E). 


\section{Dataset and Methods}

\subsection{Dataset}

We used high-resolution 3D seismic data and lithologic logs from five boreholes (see Fig. 1A, D, E), to study the Pliocene and the Pleistocene stratigraphic evolution of the western Niger Delta.

\subsubsection{Seismic data}

The 3D seismic data was processed as a zero-phas su...e wavelet in the American reverse standard polarity such that an increase in acoustı impedance corresponds to a trough (blue loop) in the wavelet, while a decrease in acoustic 1 . pedance is represented by a peak (red loop) in the wavelet. The horizontal resolutior ( $^{f}$ th $\mathrm{z}$ data is characterised by a stacking bin spacing of $25 \mathrm{~m}$ x $25 \mathrm{~m}$ (inline and crossl' ne 'pacing), and a seismic recording sampling interval of 4 milliseconds two-way travel time ( ${ }^{\top} \mathrm{NT}$ ). The dominant frequency of the data is $30 \mathrm{~Hz}$ over the first 3 seconds (TWT), which rialc s $\_$vertical resolution of $\sim 13.7$ meters within the interval of interest.

\subsubsection{Well data}

The well data comprise gamma-ray logs from five wells (labelled W1, W2, W3, W4 and W5 in Fig. 1A, D, E). Wells W2-W5 penetrate only the lower part of the Pliocene whereas W1 covers the Neogene to the late Pleistocene (see Figs. 2; 7 and 9B of Chima et al., 2019). The most recent available biostratigraphic dating corresponds to the late Messinian (circa $5.5 \mathrm{Ma}$ ), based on the last recorded occurrence of Discoaster quinqueramus (see Chima et al., 2019). 
Biostratigraphic data were not available for the interval of interest (the Pliocene and the Pleistocene).

\subsection{Methods}

\subsubsection{Seismic stratigraphy}

We applied the concept of seismic stratigraphy (after Mitchum and Vail, 1977) to analyse the sedimentary architecture of the Pliocene and Pleistocene sedirı ntary records of the western Niger Delta intraslope basins. Our seismic stratigraphic apr reflection amplitude, continuity, internal architecture, exte nal geometry, the nature of bounding surfaces and erosional truncations to delineate key seisn. - surfaces as well as their association with seismic facies.

\subsubsection{D seismic geomorphology}

We applied the 3D sejrmic geomorphological analysis technique described by Posamentier and Kolla (2003) a nd Catuneanu (2006) for our detailed study of the depositional environments corresponding in the seismic facies described above. This was achieved by detailed analysis of rou. mean square (RMS) seismic amplitudes, that makes it possible to distinguish lithological and depositional environments (see Chima et al., 2019; and references therein). Analyses of the RMS amplitudes were combined with variance seismic attributes to guide the geological interpretation of the seismic data (Chopra and Mafort, 2007; Taner et al; 1994; Chima et al., 2019). Three (3D) seismic geomorphological analyses enabled the detailed study of the space-time evolution of the Pliocene and the Pleistocene sedimentary records. 
3.2.3 Allostratigraphic partitioning and dating of the Pliocene and the Pleistocene stratigraphy

Detailed analysis of RMS maps combined with variance analysis of seismic attributes and 3D geomorphological interpretation of the seismic data made it possible to define 21 mappable seismic surfaces, which bound the fourth-and fifth-order allostratigraphic sequences as defined by Catuneanu (2006) and Catuneanu et al. (2011). These allostratigraphic units were grouped in two mega seismic units (MSU 1 and MSU 2). As no biostratigraphic data were available for the Pliocene or the Pleistocene, we used the most recent biostratigraphı lly constrained interval (the late Messinian) dated at $\sim 5.5 \mathrm{Ma}$ based on the last rezrcizi occurrence of Discoaster quinqueramus (see Chima et al., 2019), to define the age $\iota^{f}$ the lower part of MSU 1. Then, we matched the key erosional and conformable seismic surta $-s$ that show significant changes in the sedimentary architecture both in seismic lines ana in $j \mathrm{D}$ geomorphological maps with the high-

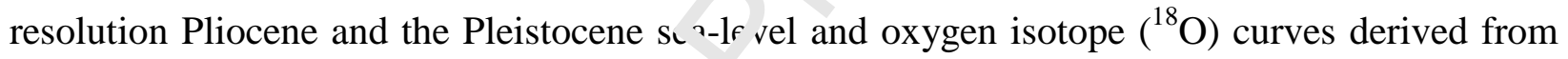
(Lisiecki and Raymo, 2005; Raymo et aı., 2018).

\section{Results and Interpretation.}

\subsection{Seismic facies analy.'s}

The Pliocene and Pleistocene stratigraphy of the western Niger Delta intraslope basins were subdivided into two mega seismic units named MSU 1 and MSU 2, based on the observed changes in seismic geometries and depositional environments. MSU 1 and MSU 2 correspond to Unit 6 and Unit 7 respectively in Chima et al. (2019). Although a detailed seismic facies analysis of the study area was presented in Chima et al. (2019) (Fig. 1A, C, D, E; 2A), the present study sheds more light on facies association and improves our understanding of depositional processes 
and sequence stratigraphy in a deep-water (slope) setting. The six seismic facies previously described in the study area by Chima et al. (2019) include: (1) chaotic, discontinuous lowamplitude $\left(B_{l}\right)$ seismic facies, characterised by elongate/tabular geometry, irregular tops and erosional bases, interpreted as mass-transport deposits (MTDs; Fig. 2A $\mathrm{A}_{1}, \mathrm{~B}, \mathrm{C}$ ); (2) chaotic, discontinuous to moderately continuous, high-amplitude $\left(B_{h}\right)$ seismic facies, characterised by irregular base, blocky external form and sinuous planform geometry, interpreted as turbidite feeder channels/aggrading or meandering channel levee comple $\varkappa_{\llcorner}$(CLCs; Fig. 2A 2 , B); (3) coherent/slightly inclined, moderate to high-amplitude seism:- icicies that generally border the margins of concave-upward negative relief and display to rous planform geometry, interpreted

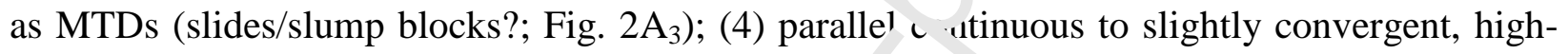
amplitude, $\left(C_{b h}\right)$ seismic facies that display fan $\mathrm{s}^{\prime}$ ' $\mathrm{pe} \mathrm{d}$ geometry with high RMS amplitude on the map, interpreted as distributary char nel /lobes $\left(2 \mathrm{~A}_{4}, \mathrm{C}\right)$; (5) convergent/thinning, high-to moderate-amplitude, $\left(C_{t h}\right)$ seismic facıs, characterised by wedge geometry, which borders negative relief, marked by sinuov piriorm geometry, interpreted as channel levee deposits $\left(2 \mathrm{~A}_{5}, \mathrm{~B}, \mathrm{C}\right) ;(6)$ transparent, pa 1 llel, continuous, draping seismic facies $(D)$ that locally display small-scale chaotic internal $n$.hitecture, bounded by conformable surfaces interpreted as hemipelagic drapes and $\iota^{-}$muddy turbidites $\left(2 \mathrm{~A}_{6}, \mathrm{~B}, \mathrm{C}\right)$. The foregoing seismic facies and their interpretations were confirmed by 3D seismic geomorphology (Figs. 3-10) and are consistent with previous studies of the Niger Delta intraslope basins (e.g. Deptuck et al., 2003; 2012; Adeogba et al., 2005; Bakare et al., 2007; Hansen et al., 2017).

\subsection{Facies association}


Seismic facies on the western Niger Delta intraslope basins display complex lateral and vertical arrangements inside and outside erosional submarine channels MSU 1 and MSU 2 (e.g. Fig. 2A, B, C).

\subsubsection{Association of seismic facies in mega seismic unit 1 (MSU 1)}

In MSU 1, we observed a $2.5 \mathrm{~km}$ wide concave-upward negative topography (185 m deep) that obstructs the lateral continuity of seismic reflections (e.g. Fig. 2B). Within this topographic feature, a narrow (1 km wide, $90 \mathrm{~m}$ deep), vath s...1 stacked, concave-upward negative topographies were also observed (e.g. Fig. 2B). $T_{1} \cdot 2.5 \mathrm{~km}$ and the $1 \mathrm{~km}$ wide negative topographies were interpreted as, respectively, erosiona ubmarine channels and channel levee systems (CLSs) or channel forms (after Deptuck $e$, ll. 2003; e.g. Fig. 2B).

\subsubsection{Association of seismic facies wit. in the erosional submarine channels in MSU 1}

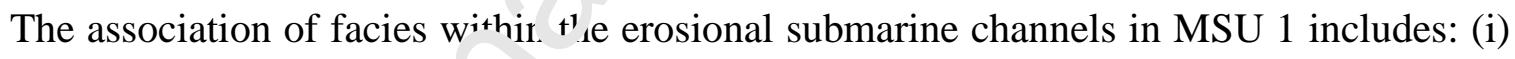
$B_{l}$ seismic facies (MTDs), naı ed vasal MTDs; (ii) $B_{h}$ seismic facies, which correspond to turbidite feeder channels/am ${ }^{\text {ra }}{ }^{\text {d: }}$ ng or meandering channel levee complexes, and (iii) $C_{t h}$ seismic facies, which correspona to channel levee deposits (e.g. Fig. 2A, B). Levee deposits were further subdivided into inner and outer levee (IL and OL) deposits, respectively, depending on whether sedimentation occurred inside or outside the erosional submarine channel (e.g. Fig. 2B). These $B_{l}, C_{t h}$ and the $B_{h}$ seismic facies generally infilled erosional submarine channels in MSU 1 (e.g. 2B). Each erosional submarine channel and associated infilling was generally abruptly overlain by another negative topography (erosional submarine channel) with or without complete 
preservation of the $B_{l,} C_{t h}$ and the $B_{h}$ seismic facies (Fig. 2B). The entire system is locally overlain by another $B_{l}$ seismic facies (MTD; e.g. Fig. 2B).

\subsubsection{Association of seismic facies outside the erosional submarine channels in MSU 1}

Outside the erosional submarine channels in MSU 1, seismic facies generally stack vertically from (i) $B_{l}$ facies (basal MTDs), (ii) the $C_{t h}$ facies (channel levee deposits), (iii) the $B_{l}$ facies (MTDs), (iv) the $C_{b h}$ facies (distributary channels/lobe depus.ts) and the $D$ seismic facies (hemipelagic drape) (e.g. Fig. 2C). The $B_{l}$ seismic facies (NTL, ) generally disrupt the lateral continuity of the underlying $C_{t h}$ seismic facies (e.g. 2C).

\subsubsection{Association of seismic facies in MSU 2}

In MSU 2, similar concave upw rd negative topographies previously described and interpreted as erosional submarine chan. ${ }^{\circ} \mathrm{ls}$ and CLSs (Fig. 2B), were also observed in MSU 2 (e.g. Fig. 3A, B). How the seismic frcies are associated inside and outside the erosional submarine channels is describec helow.

4.2.2.1 Association of se $\cdot$ mic facies within the erosional submarine channels in MSU 2

In MSU 2, the seismic facies in the erosional submarine channels generally stack from (i) the $B_{h}$ facies (turbidite feeder channels/aggrading or meandering channel levee complexes); (ii) coherent/slightly inclined, moderate to high amplitude seismic facies that generally border the margins of concave-upward negative relief and display tortuous planform geometry (slide/slump blocks) (Fig. 2A; 3A, B) to (iii) the $D$ facies (hemipelagic drape), where preserved (e.g. horizons $\mathrm{S}$ and $\mathrm{X}$ in Fig. 3A, B). The coherent/slightly inclined, moderate to high amplitude seismic facies 
(slide blocks/slump deposits) locally disrupt the lateral continuity of the underlying $B_{h}$ seismic facies (e.g. Fig. 3A, B).

4.2.2.2 Association of seismic facies outside the erosional submarine channels in MSU 2

In MSU 2, the association of seismic facies outside erosional submarine channels includes: (i) the $C_{t h}$ facies (aggrading channel levee/overbank deposits); (ii) the $B_{l}$ facies (MTDs), and (iii) the $D$ facies (hemipelagic drape) (see the su tigraphic interval between horizons $\mathrm{T}$ and $\mathrm{V}$ at the extreme left in Fig. 3A, B). As observ- 1 $_{1:}$. MSU 1, the $B_{l}$ facies (MTDs) generally disrupt the lateral continuity of the $C_{t h}$ seismic fac ies (e.g. Fig. 3A, B).

4.3 3D seismic geomorphology and sedimentary a. nit 2 cture

A total of 21 seismic surfaces (13 . N $/ S U$ 1, labelled M-P) and (8 in MSU 2, labelled Q$X$ in Figs. 3-10), were analysed in de $\cdot$ il in this study. Only a few representative erosional surfaces in the lower, middle, and ${ }^{n}{ }^{\circ}{ }^{r}$ parts of MSU 1 and MSU 2 which illustrate the main changes in the sedimentary arch' 'ecture of the Pliocene and the Pleistocene are presented here.

\subsubsection{Base of MSU 1 (ho. 'izon M)}

Description

The base of MSU 1 (horizon M in Fig. 3B) is unerlain by $>80 \mathrm{~m}$ thick transparent, parallel continuous, $D$ seismic facies (highlighted in blue in Fig. 3B). The M horizon is traceable through a significant part of the study area except across the overlying $185 \mathrm{~m}$ negative relief (horizon A in Fig. 3A) and the mounded seismic wipe out zone in the northern part of the study area (Figs. 1D, 3A, B). The $185 \mathrm{~m}$ deep relief associated with horizon A marks the onset of the 
chaotic, discontinuous low amplitude ( $B_{l}$ seismic facies), the convergent/thinning, high to moderate amplitude ( $C_{t h}$ seismic facies) and the parallel continuous to slightly convergent, high amplitude ( $C_{b h}$ seismic facies) (Fig. 3A, B). An RMS amplitude map draped on a variance attribute of the $185 \mathrm{~m}$ deep relief associated with horizon A, shows the presence of a $1.5 \mathrm{~km}$ wide, east-west trending, relatively straight planform feature (labelled 1 in Fig. 3C), and two narrow winding features (labelled 2, 3 in Fig. 3C), in the southern part of the study area. The narrow winding feature (labelled 2 in Fig. 3C), is connected to ? fan-shaped feature to the

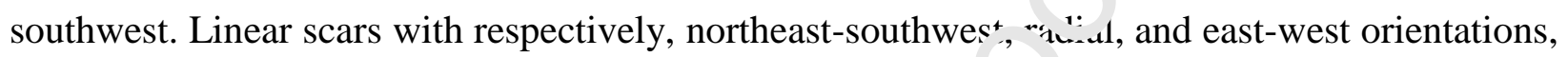
are observed in the northern, central, and southern parts oi the study area (Fig. 3C). A grey area (dashed red line) is observed in the north-eastern part on the study area characterised by radial features at its southern tip (Fig. 3C). The narrow 1 nd ng feature (labelled 3 in Fig. 3C), crosses

an oblique, elongated positive relief to th' $\mathrm{s} s \mathrm{uth}$. A north-south seismic line $\left(\mathrm{CC}^{\mathrm{I}}\right)$, (located in Fig. 3C), illustrates the sedimentary arcı itecture of horizon A (Fig. 3A, B). Northeast-southwest trending linear scars generally offs ${ }^{\wedge} \mathrm{st}^{\cdot}$. .graphy normally except in the north, where one of the scars (labelled Z in Fig. 3B) oi sets stratigraphy normally at its lower part but inversely at its upper part.

Interpretation

The $>80 \mathrm{~m}$ thick transparent, parallel continuous, draping seismic unit, characterised at the base by a conformable seismic surface (labelled horizon M in Fig. 3B), corresponds to the hemipelagic drape (HD)/muddy turbidites, dated at $5.5 \mathrm{Ma}$ (see Chima et al., 2019). The conformable nature of this hemipelagic drape suggests that it passively draped the slope during the episode of maximum flooding of the continental shelf and sediment starvation in the deep 
basin (see Chima et al., 2019; and references therein). This interpretation is supported by the fact that the D. quinqueramus (calcareous nannofossil) we used in dating the hemipelagic drape at 5.5 Ma is globally recognised as an important marker of the high sea level in the late Miocene (e.g. Backman et al., 2012). The $1.5 \mathrm{~km}$ wide and $185 \mathrm{~m}$ deep negative relief associated with horizon A (Fig. 3B), which displays straight planform geometry (Fig. 3C), corresponds to the erosional submarine channel described in section 4.2.1. The lateral discontinuity of horizon M (the base of the hemipelagic drape dated at $5.5 \mathrm{Ma}$ ) caused by the overlying hu. izon A, further supports the interpretation of the latter as an erosional surface (Fig. 3B). $T^{h} \sim \iota_{\iota}, c_{t h}$ and the $C_{b h}$ seismic facies that generally overlie horizon A correspond to, resp -tively, the MTDs, channel levee deposits/CLSs and the turbidite feeder channels/agg complexes described above (Figs. 2A, B; 3A, R). Th : narrow, winding features (labelled 2, 3) south of the main erosional submarine ch. $\mathrm{nr}_{\mathrm{i}} \mathrm{l}$ in Fig. 3C, were interpreted as sinuous channel levee systems (CLSs) or channel forms 'after Deptuck et al., 2003; Fig. 3C). The fan-shaped feature associated with CLS 2 was int reted as a transient fan/lobe deposit (after Adeogba $e t$ al., 2005; Fig. 3C). The seismic vipe out/grey area in the north-eastern part of the study area was interpreted as a mobile shrle, w'ile the linear scars and oblique/elongated feature, crossed by a CLS to the south, were 1 spectively interpreted as normal faults and buried folds (see Chima $e t$ al., 2019; Fig. 3C). The change in the stratal offset patterns along fault $\mathrm{Z}$ (Fig. 3B), from normal at the lower stratigraphic level to inverse at the upper stratigraphic level, was interpreted as fault inversion linked to shale tectonics.

\subsubsection{Middle part of MSU 1 (horizons G and I)}

Description 
An RMS amplitude map of horizon $\mathrm{G}$ draped on the variance attribute extraction in the middle part of MSU 1 (horizon G), reveals the presence of four narrow, winding features (labelled 1a, 2, 3 and 4 in Fig. 4A) located in the north-western and south-eastern parts of the study area. Compared to winding features $1 \mathrm{a}$ and 4 , features 2 and 3 display elongated borders of moderate RMS amplitudes (Fig. 4A). Linear scars display trends that vary with the northeastsouthwest and east-west orientations, dominate the northern part of the study area, while the radial patterns dominate the central part of the study area (Fiz. 4A). A NE-SW grey area subdivides the study area into northern and southern halves ${ }^{\prime} h_{1}$. 4 A). An irregular, rounded, chaotic area is visible in the SE corner of the study area (da. hed black line in Fig. 4A). A seismic line $\left(\mathrm{DD}^{\mathrm{I}}\right)$ through the winding features $1 \mathrm{a}$ and 2, revea the presence of a $1 \mathrm{~km}$ wide, $120 \mathrm{~m}$ deep relief, infilled with the chaotic, discontinucu .o noderately continuous, high amplitude, $B_{h}$ and convergent/thinning, high to moderat, ar plitude, $C_{t h}$ seismic facies that also infill erosional channels 1a and 2 (Fig. 4B).

Furthermore, a variance at+-ibl,e extraction on the horizon I, in the middle of MSU 1 (above horizon G), reveals the ${ }_{\mathrm{I}}$ resence of a $2.5 \mathrm{~km}$ wide, sinuous feature (labelled $1 \mathrm{~b}$ ) to the north, characterised by the nre ${ }^{\circ}$. ice of narrower, winding features in its central part (Fig. 5A). A chaotic area is visible o. the outer side of the main sinuous feature to the northeast, which is characterised by smaller, linear or slightly curved features (Fig. 5A). A seismic line (BB ${ }^{\mathrm{I}}$ ) crossing the main sinuous feature (Fig. 5A) reveals the presence of a $176 \mathrm{~m}$ deep relief corresponding to horizon I (Fig. 5B). The $2.5 \mathrm{~km}$ wide negative relief associated with horizon I and the enclosed narrower sinuous features are infilled with the chaotic, discontinuous low amplitude, $B_{l}$ seismic facies, the convergent/thinning, high to moderate amplitude, $C_{t h}$ seismic facies and the parallel continuous to slightly convergent, high amplitude, $C_{b h}$ seismic facies that 
generally disrupt the lateral continuity of the underlying $B_{l}$ and the $C_{t h}$ seismic facies (Fig. 5B). These seismic facies are unconformably overlain by a negative relief corresponding to horizon $\mathrm{J}$ (Fig. 5B). In turn, horizon $\mathrm{J}$ is overlain by a $166 \mathrm{~m}$ deep narrow relief, infilled with the chaotic, discontinuous to moderately continuous, high amplitude $B_{h}$ seismic facies, bordered by the convergent/thinning, high to moderate amplitude $C_{t h}$ seismic facies (Fig. 5B). The entire system is abruptly overlain by the chaotic, discontinuous low amplitude, $B_{l}$ seismic facies, covered by hemipelagic drape and display an overall convex-upward geometry ( ${ }^{\text {ig. }}$ 5B).

\section{Interpretation}

The four narrow winding features associated with orizon G in (Fig. 4A) were interpreted as CLSs or channels forms, while the moderate $a^{r}, p^{l}$ iude zones that parallel the borders of the CLSs 2 and 3 were interpreted as channel velt, (Fig. 4A). The NE-SW oriented grey area/seismic wipe-out zone corresponds to the area affected by mobile shale and/or erosion (Fig. 4A). The irregular chaotic area in the SE corror ( $f$.he study area was interpreted as MTD (Fig. 4A). The 1 $\mathrm{km}$ wide, $120 \mathrm{~m}$ deep relief as cciaıed with horizon $\mathrm{G}$ was interpreted as erosional CLS (Fig. 4B). The chaotic, discontin'יu a moderately continuous, high amplitude, $B_{h}$ seismic facies and the convergent/thinning, high to moderate amplitude, $C_{t h}$ seismic facies that respectively infill and border the erosional CLS associated with horizon G, were interpreted as turbidite feeder channels/aggrading or meandering channel levee complexes and outer levee deposits. The presence of the $C_{t h}$ seismic facies (OL) deposits at nearly the same stratigraphic level as the infill of the erosional CLSs (labelled 1a in Fig. 4B), suggests that sediment-gravity flows within the channel were unconfined (see Deptuck et al., 2003; Fig. 4B). 
The $2.5 \mathrm{~km}$ wide, sinuous feature associated with horizon I (Fig. 5A) was interpreted as a sinuous, erosional submarine channel/erosional surface, while the smaller winding features within the erosional channel were interpreted as CLSs (Fig. 5B). The chaotic, discontinuous low amplitude, $B_{l}$ seismic facies, the convergent/thinning, high to moderate amplitude, $C_{t h}$ seismic facies and the parallel continuous to slightly convergent, high amplitude, $C_{b h}$ seismic facies that infill or border the erosional submarine channel and the channel forms were interpreted, respectively, as MTDs, channel levee deposits, and distributary (น?nnels/lobes (Figs. 2B, 5B).

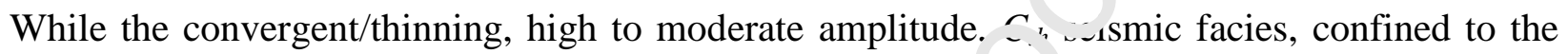
main erosional submarine channel (horizon I) was interpre $` d$ as inner levee (IL), the $C_{t h}$ seismic facies on the outer bank of the erosional channels were i cerpreted as outer levee (OL) deposits (Figs. 2B, 5B). The presence of the IL deposit $\mathrm{t}^{\prime}$ e right of the main erosional submarine channel, coupled with the narrowing and ate al shifts of the enclosed CLSs/channel forms (red arrow in Fig. 5B), were interpreted as recording different stages of meandering/lateral aggradation of the system. The rmast nre of OLs at every stage of the erosional submarine channel (Fig. 5B), suggests hat sediment-gravity flows were not confined during the development of the system. Tle convex-upward geometry, displayed by the entire system, suggests that it was over."'led.

\subsubsection{Upper part of MSU 1 (horizon K)}

Description

An RMS amplitude map draped on a variance attribute extraction in the upper part of MSU 1, (labelled horizon $\mathrm{K}$ in Fig. 6A), reveals the presence of a $1.8 \mathrm{~km}$ wide, bifurcating planform feature in the northern part of the study area (labelled 1c in Fig. 6A). The feature 
displays an overall moderate RMS amplitude and is characterised by smaller, winding features with higher RMS amplitude (Fig. 6A). A linear relief is visible on the outer bend of the main system (Fig. 6A). A north-south seismic line ( $\left.\mathrm{FF}^{\mathrm{I}}\right)$ through the centre of the system reveals a 1.8 $\mathrm{km}$ wide, $90 \mathrm{~m}$ deep negative relief, infilled with the chaotic, discontinuous to moderately continuous, high amplitude, $B_{h}$ seismic facies (Fig. 6B). The $B_{h}$ seismic facies is unconformably overlain by the chaotic, discontinuous low amplitude, $B_{l}$ seismic facies, covered by hemipelagic drape and display an overall convex-upward geometry (Fig. 6B).

Interpretation

The $1.8 \mathrm{~km}$ wide, $90 \mathrm{~m}$ deep relief, characterised ᄂ.' moderate RMS amplitudes and the enclosed, narrow winding features that display higher $\therefore$. $\mathrm{S}$ amplitudes were interpreted as an erosional submarine channel and CLSs, respective'v ( Fig. 6A, B). The chaotic, discontinuous to moderately continuous, high amplitude, $\mathrm{L}, \mathrm{s}$-ismic facies which infill the erosional submarine channel were interpreted as turbidite $t{ }^{\curvearrowright}$ der channels/aggrading or meandering channel levee complexes, while the overlying, inco if Jrmable, $B_{l}$ seismic facies were interpreted as MTDs (Fig. 5B). The sharp relief at th ouler bend of the erosional submarine channel was interpreted as a terrace (Fig. 6A, B). The f it this feature matches the earlier erosional submarine channels (labelled 1a-c in Figs. 4i JA and 6A), suggests that the feature has been active since the time equivalent to horizon E (Fig. 4A). Between the early stage (labelled 1a in Fig. 4A) and the late stage (labelled 1c in Fig. 6B), this erosional channel migrated more than $10 \mathrm{~km} \mathrm{NW-SE}$, with an overall increase in width and erosional efficiency until the age equivalent to that of horizon $\mathrm{K}$, when it was truncated by the overlying, $B_{l}$ seismic facies (MTDs; Fig. 6B). The convex-upward geometry, displayed by the entire system, suggests that it was overfilled. 


\subsubsection{Base of MSU 2 (horizon Q)}

\section{Description}

An RMS amplitude map at the base of MSU 2 draped on a variance attribute map (the horizon labelled Q in Fig. 3B), reveals the presence of a 2.5-km wide, sinuous NE-SW trending feature and smaller, NE-SW winding features (labelled 1, 2, 3 and 4, respectively, in Fig. 3D), all in the southern part of the study area. In the northern part of the study area, linear scars display east-west, northeast-southwest and radial patterns from the distai central to proximal parts, respectively (Fig. 3D). Towards the northeast, two large dark nu- ned features (>1.5 km wide), characterised by low RMS amplitudes are flanked by sma.' 'er, dark rounded features (Fig. 3D). The large, dark rounded feature to the extreme north-e ? is marked at its centre by a $0.3 \mathrm{~km}$ wide, rounded feature (Fig. 3D). In the north-west $\mathrm{n}$ art of the study area, a $1 \mathrm{~km}$ wide sinuous feature highlighted in grey, marks the $\mathrm{nc}$ th $\mathrm{f}$ in limit of the small, dark rounded features (Fig. 3D). A north-south seismic line (CC, crossing these features, illustrates their stratigraphic architecture (Fig. 3A, B).

\section{Interpretation}

The $2.5 \mathrm{~km}$ wide, NE-SW trending feature (labelled 1 in the southern part of Fig. 3B, D) and the sinuous feature highlighted in grey to the northwest, correspond to the eroded portion of the stratigraphy, while the narrow winding features (labelled 2, 3 and 4 in Fig. 3D) were interpreted as CLSs. The east-west and northeast-southwest trending as well as radial scars (Fig. 3D) that offset stratigraphy on seismic line (Fig. 3B), were interpreted as normal faults. The large and smaller, dark rounded features in the northern part of the study area were interpreted as mobile shales and fluid escape features, respectively (Fig. 3D). The $0.3 \mathrm{~km}$ wide, rounded 
feature in the centre of the mobile shale to the northeast was interpreted as a giant pockmark (after Ribolout et al., 2012).

\subsubsection{Middle part of MSU 2 (horizon R)}

Description

An RMS amplitude map in the middle of MSU 2 superimposed on a variance attribute extraction (the level of horizon $\mathrm{R}$ in Fig. 7C) reveals the presence $\iota^{f}$ a NE-SW trending, $2.5 \mathrm{~km}$ wide sinuous feature, with low RMS amplitude (Fig. 7A, B . $7_{1}:$ sinuous feature increases in width downstream to the southwest and is characterised by nany smaller winding features within the main system (Fig. 7A, B). Rounded relief features $>>, 00 \mathrm{~m}$ wide are present on the middle outer bend of the system (Fig. 7A, B). Three narr $v$ s/inding features are observed south of this sinuous feature, (Fig. 7A, B). Radial, NE SW and E-W trending linear scars occur in the north, central and southern parts of the study aı:a, respectively (Fig. 7A, B). To the north, two rounded, dark features with low RMS ampli^^dc sre observed associated with the lower feature, flanked by smaller rounded, dark featurc which are confined within the NE-SW and E-W trending linear scars (Fig. 7A, B). A nor ${ }^{\text {th }}$-se ${ }^{\prime} \cdot n$ seismic line $\left(G^{I}\right)$ through the main sinuous feature, reveals the presence of a 185- $n_{1}$ deep, negative relief, characterised by elevated margins and irregular scars to the right of the feature (Fig. 7C, D, E). The 185-m deep relief is infilled with chaotic, discontinuous to moderately continuous, high amplitude, $B_{h}$ seismic facies, which in turn, are unconformably overlain by the coherent/slightly inclined, moderate to high amplitude seismic facies (Fig. 7C, D, E). The infill of the relief associated with horizon $\mathrm{R}$ is unconformably overlain by a $180 \mathrm{~m}$ relief and a $100 \mathrm{~m}$ deep relief that correspond, respectively, to horizons $\mathrm{V}$ and $\mathrm{W}$ (Figs. 7C, D, E; 8D, E). These topographies are in turn infilled with chaotic, 
discontinuous to moderately continuous, high amplitude, $B_{h}$ seismic facies and coherent/slightly inclined, moderate to high amplitude seismic facies (Fig. 7C, D, E). The entire system is overlain by an irregular seismic reflection (horizon $\mathrm{X}$ ), which, in turn, is covered by transparent, parallel continuous, $D$ seismic facies (Fig. 7C, D, E).

\section{Interpretation}

The $2.5 \mathrm{~km}$ wide, $185 \mathrm{~m}$ deep sinuous feature, associated with horizon $\mathrm{R}$ was interpreted as a sinuous erosional submarine channel (Fig. 7A-E). The $\mathrm{c}^{\mathrm{h}} \sim \mathrm{n} \mathrm{i}$, discontinuous to moderately continuous, high amplitude, $B_{h}$ seismic facies and the cu herent/slightly inclined, moderate to high amplitude seismic facies that infill the erosional cha. .els/erosional surfaces associated with horizons $\mathrm{R}, \mathrm{V}$ and $\mathrm{W}$ (Fig. 7A-E) were interp $\mathrm{rt}^{+} \mathrm{d}$ as turbidite feeder channels/aggrading or meandering channel levee complexes ar. J TTDs (slides/slump blocks?), respectively. These turbidite feeder channels/aggrading or $\mathrm{n}_{\text {. }}$ andering channel levee complexes resemble the highly incisional, high amplitude reflectins (U ARS) previously described on the western Niger Delta slope (e.g. Deptuck et al., 2003, Yeitiö and Davies, 2007; Hansen et al., 2017) and elsewhere on the adjacent side of the ecratu-ial Atlantic, the Rio Muni Basin (Equatorial Guinea) (see Jobe et al., 2011). The transpart ${ }^{-}$, parallel continuous, $D$ seismic facies, which drape the entire system was interpreted as a hemipelagic drape (Fig. 7C-E). The $>300 \mathrm{~m}$ wide, rounded features on the middle outer bend of the erosional submarine channel were interpreted as slides/slump scars (Fig. 2A, 7A, B). The narrow, winding features to the south of the main erosional channel were interpreted as sinuous CLSs or channel forms (see Deptuck et al., 2003; Fig. 7A, B). The lateral discontinuity of seismic reflections (e.g. the horizons P and Q) on the adjacent side of the erosional channel (Fig. 7C-E), demonstrates the erosional character of the sediment-gravity 
flows that sculpted the channel. This interpretation is supported by the channel's deeply incised nature (185-m deep) and the presence of terraces (multiple slide/slump scars) along the elevated margins of the channel (Fig. 7C-E). The relatively confined nature of the erosional submarine channels, the dominance of channel infills by turbidite feeder channels/aggrading or meandering channel levee complexes within the channels and the presence of MTDs (slides/slumps?), distinguish the submarine channels observed in MSU 2 from those observed in MSU 1, where the channels are generally unconfined (e.g. Figs. 4B, 5B). The veriı al superposition of erosional submarine channels with minor lateral migration (Fig. 7C-E) denenstrates the complex cut and fill architecture of the system with overall vertical aggradai on (red arrow in Fig. 7E). The radial, E-W and NE-SW trending linear scars distributed in the orth, central and southern part of the study area, were interpreted as normal faults (Fig / F -C). The rounded, dark features with low RMS amplitudes were interpreted as mob: e s'tales, while the smaller, dark rounded features that flank the mobile shales were interprete. ${ }^{\prime}$ as fluid escape features (Fig. 7A, B). These mobile shales, mud volcanoes, fluid escrne ertures, BSR and pockmarks (Figs. 1E, 3A, 8A, 9A), support fluid overpressure in the stuay area (see also Riboulot et al., 2011).

\subsubsection{Upper part of the NiSU 2 (horizons $\mathrm{V}$ and $\mathrm{W}$ )}

Description

An RMS amplitude map of horizon $\mathrm{V}$ draped on a variance attribute extraction at the upper part of MSU 2 reveals the presence of a $2.1 \mathrm{~km}$ wide, sinuous planform feature, characterised by moderate RMS amplitudes and smaller winding features within the main system

(Fig. 8A, B). Smaller winding features also occur in the northern and southern parts of the study area (Fig. 8A, B). The borders of the main sinuous system are irregular and contain some 
detached curved loops at its outer bends (Fig. 8A, B). North of the system, a NE-SW trending, wedge-shaped chaotic area of low RMS amplitude is observed (dashed black lines in Fig. 8A, B). Further to the north of the study area, two rounded, dark features with low RMS amplitudes are associated with smaller, dark rounded features (Fig. 8A, B). Some of the smaller, dark rounded features are confined within the NE-SW trending short and long linear scars (Fig. 7A, B). A NW-SE seismic line $\left(\mathrm{HH}^{\mathrm{I}}\right)$ illustrates a $105 \mathrm{~m}$ deep negative relief associated with the $2.1 \mathrm{~km}$ wide sinuous feature (Fig. 8C-E). This feature is infilled wili chaotic, discontinuous to moderately continuous, high amplitude, $B_{h}$ seismic facies whic:-, in turn, are unconformably overlain by the coherent/slightly inclined, moderate to high amplitude seismic facies (Fig. 8C-E). The infill of the erosional channel/surface associated $v$ in horizon $\mathrm{V}$ is abruptly overlain by another $100 \mathrm{~m}$ deep relief associated with the $\mathrm{N}$.1v ng horizon W (Figs. 7C-E; 8C, 9A). The topographies of horizons $\mathrm{V}$ and $\mathrm{W}$ resp tiv dy disrupt the lateral continuity of the relatively thick, convergent/thinning, high to $\mathrm{t}$. nderate amplitude, $C_{t h}$ seismic facies, the parallel continuous to slightly convergent, r: oh a'nplitude, $C_{b h}$ seismic facies, and the draping, $D$ seismic facies (Fig. 7C, 8C). Towards ti e right of Fig. 8C, thin, laterally confined, somewhat coherent, low to moderate reflectivity $s^{-i}$,mic reflections overlie horizon V (above the V-shaped, linear scars, that offset seismic atlections in Fig. 8A-C).

An RMS amplitude map superimposed on a variance attribute map (the level of the horizon $\mathrm{W}$ ), just above (the horizon $\mathrm{V}$ ), reveals the presence of a $2.5 \mathrm{~km}$ wide, sinuous planform feature with low RMS amplitudes and characterised by narrow winding features (Fig. 9A). South of the main sinuous system, two elongate features, characterised by high RMS amplitudes in the eastern and western parts of the study area are observed, with narrow, winding features crossing the eastern elongate feature (Fig. 9A). To the north, two rounded, dark features are flanked by 
short and long linear scars that are in turn, flanked by smaller, dark rounded features (Fig. 9A). An irregular chaotic area with an overall low RMS amplitude to the northeast (dashed black line in Fig. 9A), occurs adjacent to the rounded, dark features (Fig. 9A). An E-W oriented seismic line $\left(\mathrm{JJ}^{\mathrm{I}}\right)$ which crosses the elongated features with high RMS amplitudes in the southern part of the study area, shows their high reflectivity and onlapping geometry at the margin of the intraslope basin (yellow arrow in the top left-hand corner of Fig. 9B). Although our observations of the previous seismic lines show that the infills of negative topoy. aphies are generally chaotic and difficult to trace (e.g. Figs. 3A, B, 7C, D), the erosional s....facos (labelled horizons X and W in Fig. 8C-E), were locally correlated inside the negative rt. ${ }^{\text {ef. }}$

Interpretation

The wide sinuous features associ, ted with horizons V and W (Figs. 8A, B; 9A) were interpreted as meandering, erosional suı marine channels, while the narrow winding features to the north and south of these featur ve interpreted as sinuous CLSs or channel forms. (Figs. 8A, B; 9A, B). The chaotic, dis ntmuuous to moderately continuous, high amplitude, $B_{h}$ seismic facies and the coherent/slinht $t_{1} ;$. $c$ clined, moderate to high amplitude seismic facies that infill the erosional submarine chaı nels associated with horizons $\mathrm{V}$ and $\mathrm{W}$ were respectively interpreted as turbidite feeder channels/aggrading or meandering channel levee complexes and MTDs (?slide blocks/slump deposits) (Fig. 8A-E). The occurrence of the slide/slump deposits at the same stratigraphic level as the laterally extensive MTDs that overlie the erosional surface (labelled horizon V; e.g. Fig.8C-E), suggests that the former may derive from failures of the latter during major sediment-gravity flows. The $D$ seismic facies interpreted as hemipelagic drape/muddy turbidites, where preserved, generally drape the erosional submarine channels and their infilling 
(Fig. 7C-E, 8C-E). The detached, curved loops on the outer bends of the erosional channel associated with horizon $\mathrm{V}$ were interpreted as abandoned meander loops (Fig. 8A, B). The chaotic areas with overall low RMS amplitudes north and northeast of the study area (Fig. 8A, B) were interpreted as MTDs. The moderate RMS amplitudes associated with the MTDs to the northeast of the rounded, dark features (mobile shales; Fig. 7A), suggest the presence of sands within the MTDs that were trapped within local topography associated with the mobile shales (Fig. 8A, B). The short, east-west trending linear scars, adjacent $\backsim$ the mobile shales and the associated small, dark rounded features, were interpreted as $f_{\cdots} \cdots 1<\_$ars and fluid escape features, respectively (Fig. 8A). The longer linear scars confin d within the shorter (fault scars), characterised by coherent/slightly deformed internal ichitecture with moderate to high reflectivity on the seismic line (e.g. Fig. 2B, 5A re interpreted as mobile shale-derived MTDs (see Chima et al., 2019). The lateral con' ne' 1 ent of these MTDs adjacent to the mobile shales (Figs. 8A, 9A), coupled with their some hat coherent internal architecture and moderate to high RMS amplitudes, distinguish them fi ${ }^{\prime} .1$ the regional MTDs (see Chima et al., 2019). The elongated features, characterise by nigh RMS amplitude in the southern part of the study area (Fig. 9A), were interpretad a iransient fan/lobe deposits (after Adeobga et al., 2005). The winding features (CLSs, that cross the eastern transient fan/lobe suggest that sediment was bypassed on the eastern transient fan to a more distal setting beyond the limit of the 3D block we studied (Fig. 9A). The upward decrease in the thickness of slide/slump deposits from horizons R to W (Figs. 7C-E, 9C-E) suggests an overall decrease in the incisional ability of the sedimentgravity flows that sculpted the systems, or the gradual establishment of a local slope equilibrium profile in response to an overall decrease in shale tectonics. However, the upward decrease in the thickness of outer levees from the horizons R-W (Figs. 8C-E, 9C-E), suggests increased 
confinement of sediment-gravity flows, or an overall decrease in the mud fraction of the former. The overall concave upward topography associated with erosional submarine channels in MSU 2, suggests that, prior to hemipelagic draping (e.g. Figs. 7C-E, 8C-E), they were underfilled compared to MSU 1, where erosional submarine channels were generally overfilled (e.g. Fig. $5 B)$.

Based on the foregoing observations, three major changes occurred in the sedimentary records of the western Niger Delta intraslope basins over the last 'J.5 Ma (see Figs. 3-10). These changes include (1) the lower part of MSU 1 at the transition ho....een the late Messinian thick hemipelagic drape dated at 5.5 Ma (horizon M) to the ov "lying erosional surface (horizon A), characterised by relatively confined, erosional submarine iannels, thin MTDs and channel levee deposits (e.g. Fig. 3A, B); (2) the upper part of $\mathrm{V}^{\mathrm{N}} \mathrm{J}$, at the transition between horizons $\mathrm{G}$ and I, dominated by thick, laterally extensiv $N$. TDs and partially confined, repetitive incisional submarine channels/erosional surfaces, v' ith complex cut and architecture (e.g. Figs. 2A, 3A-C, 5A, B, 6A, B); (3) the transition $\mathrm{b}^{-}{ }^{+}{ }^{-}, \mathrm{MSU} 1$ and MSU 2 (horizons $\mathrm{P} / \mathrm{Q}$ ), which marks the onset of repetitive, highly incisi nal, submarine channels/erosional surfaces that are infilled with aggrading/meandering chnn c $^{\prime}$ evee complexes, thin MTDs and hemipelagic drapes (where preserved; see for e.g. $\mathrm{Fl}_{\varepsilon}$ ร. 3A, B, 7C-E 8C-E).

\subsection{Sequence stratigraphic interpretation of MSU 2}

The preceding 3D geomorphological analysis reveals that MSU 1 and MSU 2 present different seismic facies and morphology (Figs. 3-10). Using the biostratigraphically constrained late Messinian (5.5 Ma), the modern seafloor (0 Ma), and taking the observed changes in the sedimentary architecture into account (Figs. 3-10), we suggest that the change at the transition 
between MSU 1 and MSU 2 (P/Q) boundary could have occurred around 0.8-1.0 Ma during the Middle Pleistocene Transition (MPT) as described in the literature (0.8-0.9 Ma; Miller et al., 2005; Lisiecki and Raymo; 2007; Fig. 10B, C). The eight seismic reflections identified in MSU 2 (horizons Q to $\mathrm{X}$ in Figs. 3-10), could represent eight fifth-order erosional surfaces (sequence boundaries). The hemipelagic drape, which marks the transition between MSU 1 and MSU 2 (horizon P), correlates with the moderate oxygen isotope (3.5\%) and moderate sea-level variations $(\sim 12.5 \mathrm{~m})$, before the more pronounced sea-level cycles $\vee$ ith amplitudes reaching 100 m (Fig. 10B, C). This hemipelagic drape (horizon P), like hor: $=1$, $\because$ at the lower part of MSU 1, was inferred to have been deposited during an overall hig. relative-sea level (see Chima et al., 2019 and references therein). The assigned age $(0.8-1$. Ma) agrees with that attributed by Benjamin et al. (2015), who suggested that th's - on ormable seismic surface belonged to the middle Pleistocene. The repetitive motif cc ssisting of vertically stacked erosional submarine channels, infilled with aggrading/meaı tering channel levee complexes (CLCs) and MTDs (slides/slumps?), and hemipelagic ${ }^{\top} \mathbf{r a}_{\mathbf{1}}$ e , (where preserved), e.g. (Figs. 3A, B; 7C-E; 8D, E), appear to record the regressive- -ansyressive cycles previously documented on the eastern Niger Delta continental shelf (e.c $\mathrm{F}_{\mathrm{a}^{+}} \sim \mathrm{ke}$ and Bhattacharya, 2010; Jermannaud et al., 2010; Riboulot et al., 2011). Similar architectural elements have been documented in the deep-water setting, offshore the Rio Muni Basin (Equatorial Guinea), where the development of submarine canyons and their infilling turbidite systems were linked to a combination of allocyclic (relative sea level, tropical storms and tectonics), and autocyclic forcing, linked to submarine channel avulsions (see Jobe et al., 2011). What is more, the submarine channels with similar architectural features described in this study (Figs. 3-10), have been recorded in the deep-water Bowser Basin, 
Northern British Columbia (Canada), where slope gullies and their infilling turbidite systems were linked to relative sea-level changes and local slope failures (Ricketts and Evenchick, 1999).

From the foregoing observations, it is reasonable to infer that the erosional surfaces observed in MSU 2 (horizons Q-X), notably, the repetitive, highly incisional submarine channels associated with horizons R, S, V, W and X (e.g. Figs. 3A, B; 7C-E, 8C-E), could represent what we call 'the falling stage erosional surfaces' (FSESs; Fig. 12), equivalent to the basal surface of forced regression (BSFR) that are generally observed on the contint. tal shelf (see Jermannaud $e t$ al., 2010; Roby et al., 2011; De Gasperi and Catuneanu, 201^; (_.mneanu, 2020). Where deeply incised, the FSESs are locally overlain by the previously tescribed basal MTDs or the bypass facies (e.g. Fig. 5B), which we interpreted as the fallin $n_{\succsim}$ tage systems tracts (see Posamentier and Kolla, 2003; De Gasperi and Catunern. 014; Catuneanu, 2020). The infilling, aggrading/meandering channel levee $\operatorname{com}_{\mathrm{r}}{ }^{\prime} \mathrm{ex}$-s (CLCs) and MTDs (slide/slumps?) (Figs. 3A, B; 7C-E; 8C-E), were interpreted as low ${ }^{+}$and to early transgressive systems tracts, while the hemipelagic drapes that generally $\sim \mathrm{v}, \mathrm{r}$ ihe entire system (where preserved) (e.g. Figs. 3A, B; 7C-E; 8C-E), were interpreted a. late transgressive to highstand systems tracts (see Posamentier and Kolla, 2003; De Ganne: and Catuneanu, 2014; Catuneanu, 2020). These architectural elements are rarely coı nletely preserved either inside or outside the erosional submarine channels due to incessant mass wasting on the western Niger Delta slope (e.g. Figs. 2-10).

The estimated duration of the sequence in MSU 2 (see section 4.6 below), suggests that these architectural elements may have been controlled by glacio-eustatic sea-level oscillations over the last circa 0.8-1.0 Ma (see Miller et al., 2005; Lisiecki and Raymo; 2007; Fig. 10B, C). The estimated age of the last erosional surface in MSU 2 (horizon X; Figs. 3A, 10B, C) was interpreted as the LGM, at around $\sim 20 \mathrm{ka}$, as also suggested by Jobe et al., (2015; 2016). 


\subsection{Sequence stratigraphic interpretation of MSU 1}

Based on the above interpretation of MSU 2, MSU 1 could correspond to a deposition between $5.5 \mathrm{Ma}$ and $0.8 \mathrm{Ma}$ (horizons M-P), with the 11 erosional surfaces (labelled A to $\mathrm{K}$ ), representing 11 fourth-order FSESs (sequence boundaries; Fig. 10B, C). Although, we included the hemipelagic drape (horizon M, dated at 5.5 Ma) in MSU 1 for calibration of the lower part of the MSU 1, the overlying erosional surface (labelled horizon $f_{1}$, which marks the onset of MTDs and channel levee deposits (Fig. 3B), was interpreted $\because 1:$ actual basal limit of MSU 1 . The erosional surface associated with horizon A correlates with a high oxygen isotope value (> $4.5 \%$ ), and one of the highest falls in the relative sea-lt $\sim 1(>25 \mathrm{~m})$ during the early Pliocene (Fig. 10B, C). We suggest an age of 4.9 Ma for th 1 \& $5 \mathrm{~m}$ deep erosional surface, reasoning that it could be correlated with the first majo. $\mathrm{fa}^{\mathrm{a}}$. in sea level just after the late Miocene (5.5 Ma) high sea level (see Miller et al., 2005; Li -iecki and Raymo, 2007; Raymo et al., 2018; Fig. 10B, C). The 4.9 Ma we propose for thic erc ci jnal surface (horizon A in Fig. 10B, C), disagrees with the late Miocene proposed by $\mathrm{i}$ njamin et al. (2015), who lacked biostratigraphic control. The occurrence of the A horjøn ; "st above the hemipelagic drape dated at 5.5 Ma, its erosional character (Fig. 3A-C, ハ・E, 8C-E), and association with MTDs and CLSs, further support its nomination as a possible candidate for the fall in sea level in the early Pliocene around 4.9 Ma (see Miller et al., 2005; Lisiecki and Raymo, 2007; Raymo et al., 2018; Fig. 10B, C).

The transition at the upper part of MSU 1 (the G/I interface), is an 120-m deep erosional surface (e.g. Fig. 4B), which tentatively correlates with a (> 30) $\mathrm{m}$ fall in the relative sea level and relatively high oxygen isotope (> 3.5\%) (Fig. 10B, C). The erosional character of this surface coupled with its association with multiple CLSs (e.g. Fig. 4A, B), suggest that it could 
have developed during a lowering of the relative sea level. The $176 \mathrm{~m}$ deep relief associated with horizon I (just above horizon G in Fig. 5B) and its complex cut and fill architecture, resemble the erosional submarine channels observed in MSU 2 (e.g. horizons R, V, W in Figs. 7, 8, 9A). The $176 \mathrm{~m}$ deep erosional submarine channel associated with horizon I and the overlying basal MTDs (bypass facies; e.g. Fig. 5B), could be interpreted as the falling stage erosional surface (FSES) and falling stage systems tracts, respectively (see Posamentier and Kolla, 2003; De Gasperi and Catuneanu, 2014; Catuneanu, 2020. Similarly, un infilling turbidite feeder channels/aggrading or meandering CLCs (e.g. Fig. 5B) could La i...trpreted as lowstand to early transgressive systems tracts, while the overlying hemipc'rgic drape could represent the late transgressive to highstand systems tracts (e.g. 5B, 6B).

The transition from CLS dominated inter as to repetitive, highly incisional submarine channels and mass-wasting dominated int ${ }^{r} v^{*}$ s is visible around horizons $\mathrm{G}$ and I (e.g. Figs. 3, 4, 5). This change in the sedimentary an hitecture could be associated with a fall in the relative sea level probably during the earlv $\mathrm{Pl}$ ic ocene, following the Northern Hemisphere Glaciation (NHG), which, in the literature, . s documented to have occurred around 2.6 Ma (see Miller et al., 2005; Lisiecki and Raymo ? $\cup^{\urcorner 7}$, Gibbard et al., 2010; Head and Gibbard, 2015a, b; Gibbard and Lewin, 2016; Raymo et c $^{\prime}$, 2018; Fig. 10B, C). Hence, we propose erosional surfaces G and I as possible candidates for the early Pleistocene but favour the latter due to its repetitive, incisional and aggrading/meandering patterns that resemble those described in the deep-water western Niger Delta over the last circa $120 \mathrm{ka}$ as controlled by glacio-eustatic sea-level oscillations and sediment supply (see Jobe et al., 2015; 2016).

4.6 Sequence duration and sedimentation rates in MSU 1 and MSU 2 
Sequence duration measures the ratio of the time interval for seismic unit development to the number of enclosed seismic surfaces (see Zhang et al., 2019). Using the estimated ages above, the sequence duration for MSU 1 yields $(5.5-0.8) \mathrm{Ma} / 13=\sim 0.4 \mathrm{Ma}(\sim 400 \mathrm{ka})$ and $(0.8-0)$ $\mathrm{Ma} / 8=\sim 0.1 \mathrm{Ma}(\sim 100 \mathrm{ka})$ for MSU 2 . Using an average velocity of $1253.2 \mathrm{~m} / \mathrm{s}$ obtained from Well-1 (W1) (Fig. 1E), the estimated sedimentation rates in non-decompacted MSU 1 and 2 are132 $\mathrm{m} / \mathrm{Ma}$ and $370 \mathrm{~m} / \mathrm{Ma}$, respectively.

\section{Discussion}

We discuss the Pliocene and Pleistocene stratigr $a_{1}$ hic evolution of the western Niger Delta intraslope basins over the last 5.5 Ma in relation , allocyclic (glacio-eustatic) sea-level and basin tectonic forcings, and propose a deep-`袖 $\lrcorner$ r lepositional model.

\subsection{Allocyclic (glacio-eustatic) sea-leves ‘ orcing}

Allocyclic factors refer to $\sim$ n. ${ }^{r}$ is that are unrelated to the depositional system; these include climate, eustasy, tectonı s and sediment supply (Einsele et al., 1991). Orbital parameters,

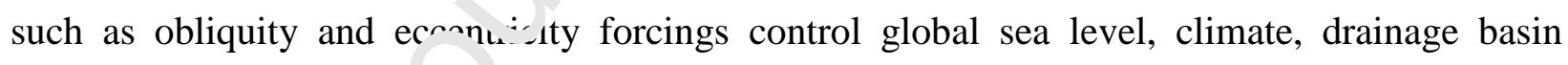
erosion, sediment supply, and more locally, environmental energy, and consequently influence the architecture of sedimentary units and their bounding surfaces (Zecchin, 2007; 2010; 2012; Catuneanu and Zecchin, 2013).

High subsidence rates $(350 \mathrm{~m} / \mathrm{Ma})$ offset by high sedimentation rates $(36.5 \mathrm{~cm} / \mathrm{ka})$ have been shown to facilitate the preservation of eccentricity sequences of $100 \mathrm{ka}$ on the eastern Niger Delta continental shelf over the last circa 0.5 Ma (Riboulot et al., 2012), in agreement with observations of the Mediterranean margin over the last circa $0.5 \mathrm{Ma}$, where subsidence rates as 
high as $255 \mathrm{~m} / \mathrm{Ma}$, accompanied by high sedimentation rates, enabled preservation of $100 \mathrm{ka}$ eccentricity sequences, linked to glacio-eustatic sea-level oscillations during the Quaternary (see Rabineau et al. 2006; Leroux et al., 2014). Although we did not estimate subsidence rates over the last circa 5.5 Ma, the overall increase in the sedimentation rates (x3) at the MPT (0.8-1.0 Ma), possibly accompanied by high subsidence rates (see Goudie, 2005), is inferred to have facilitated the preservation of the 100 ka sequences we observed in MSU 2. This interpretation is also in agreement with that of Gulick et al. (2012), who documeit $-d$ an overall increase in the sedimentation rates at a source-to-sink-scale on the New Jers eustatic changes in sea level over the last 0.7-1.2 Ma.

Although the $400 \mathrm{ka}$ eccentricity sequences we, . opose for MSU 1 are recognized to have strongly influenced sedimentation in ocean 'asi is (e.g. Pälike et al., 2006; Boulila et al., 2011), eccentricity has rarely been descri red in the deep basin architecture. MSU 1 displays a $400 \mathrm{ka}$ sequence duration and is cha"acterised by the ubiquity of discontinuous seismic reflections, the preponderance of $\mathrm{re}_{\varepsilon}$ ir nal MTDs and erosional surfaces, characterised by complex cut and fill architectu e in the upper part of the unit (Fig. 3A, B, 5A, B). These architectural features resembi- he fourth-order incised valleys/slope canyons on the Foz do Amazonas continental sit that were biostratigraphically constrained and, based on seismic records, calibrated as $400 \mathrm{ka}$ eccentricity sequences in the Pliocene (see Gorini et al., 2014). Based on the repetitive motifs of erosional surfaces, the infilling aggrading/meandering channel levee complexes, hemipelagic draping (Figs. 3-10) and the sequence durations estimated in MSU 1 and MSU 2, our interpretation is that depositional sequences in the two units were organised in $400 \mathrm{ka}$ and 100 ka sequences, respectively (Fig. 10B, C). 
The Pliocene and the Pleistocene stratigraphy of the western Niger Delta intraslope basins, respectively characterised by mass-wasting and turbidite sequences, and by hemipelagic drapes and turbidite sequences (Figs. 3-10), is also comparable with the Pliocene and the Pleistocene stratigraphy of the Ulleung Basin, East Sea (Japan), which is characterised by, respectively, debris-flows and turbidite sequences, and hemipelagic drapes and turbidites sequences (see Yoo et al., 2017). In the Ulleung Basin, the Pliocene stratigraphy is mainly linked to tectonic deformation, while the Pleistocene is linked to changes in the relative sea level (Yoo

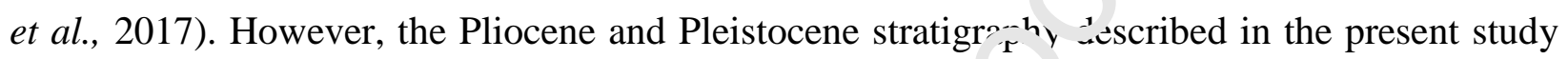
contrasts with that of the northern Gulf of Mexico (GOM), vhere tectonic subsidence is reported to have facilitated thick hemipelagic sedimentation/mua : turbidites and thin MTDs during the Pliocene compared to the Pleistocene, which is de.lir ated by thick MTDs and thin hemipelagic sediments (Madof et al., 2017; Wu et al., 20 .J; Catuneanu, 2020). Madof et al. (2017) and Wu et al. (2020), showed that the stratigrapı:y of the northern Gulf of Mexico over last 3.7 Ma was mainly controlled by differential sedin ar.tation and associated salt-related subsidence, while the overall increase in sedimentatio. rates over the Pleistocene was largely controlled by the capture of the Ohio and Missouri Pive*- oy the Mississippi in the late Pleistocene (see also Prather et al., 1998).

Pliocene and Pleistocene stratigraphy in the western Niger Delta intraslope basins was controlled by a combination of glacio-eustasy and shale tectonics (see discussion below). The observed increase in the sedimentation rates at the MPT (0.8-1.0 Ma), could be linked to (i) glacio-eustatic sea-level forcing linked to the Milankovitch cycles; (ii) regional climate forcing associated with the West African Monsoon, which has been shown to have interacted with drainage basins, erosion, and the supply of sediment to the Niger Delta since the Plio-Quaternary 
(see Lézine et al. (2005; Weldeab et al., 2011; Collins et al., 2014; Govin et al., 2014; Armitage et al., 2015); (iii) a possible shift in sediment fluxes from the eastern to the western Niger Delta over the Pleistocene due either to delta lobe switching/regional climate evolution (see Jermanaud et al., 2010; and references therein), or tectonic reorganisation of the catchment (e.g. Goudie, 2005). A recent study by Picot et al. (2019) in the adjacent Congo Basin demonstrated an overall architectural submarine channels avulsion that can be applied to most progradation/retrogradation patterns in response to climate forcing.

\subsection{Basin tectonics}

In terms of basin tectonics, control of the Plinci ed and Pleistocene stratigraphy of the western Niger Delta intraslope basins, Chima $e_{\text {. al }}$ (2019), showed that the main erosional submarine channel in the study area (lat 1le $\_$1, 2, 3; Fig. 11A, B), has been active since the Pliocene, and was generally deflected in the southern part of the study area with east-west orientation during the early and lat ac iv e periods of mobile shales (stages 1 and 3 in Fig. 11A, B), and northwards, with a nu theast-southwest orientation during quiescent shale tectonics (stage 2 in Fig. 11A, B) In 5 present study, we investigated the entire submarine channel systems over the last 5.5 Ya, and provide a better understanding of the control of basin tectonics and_deep-water depositional systems (Fig. 11A, B).

The progressive shift of erosional submarine channel levee systems from the NW to the SE in MSU 1 (stages 1a-c; Fig. 11A) could be linked to avulsion events in response to (i) shale tectonics or (ii) changes in sediment supply. Similarly, the absence of submarine channels in the northern part of the study area in MSU 2 (Fig. 11B) could be due to (i) up-dip channel avulsions in response to the movement of mobile shales (see also Clark and Cartwright, 2012; Jolly et al., 
2016) or (ii) shifting of the depositional axis further NW, away from the study area. The lateral variation in the stratigraphic thickness of MSU 1 (5.5 to 0.8-1.0 Ma), compared to MSU 2 (0.81.0 to $0 \mathrm{Ma}$ ), suggests that shale tectonics was more active in the Pliocene than in the Pleistocene (e.g. Figs. 3B, 10B). The presence of mobile shales, mud volcanoes, pockmarks, BSR, fluid escape features and mobile shale-derived MTDs (see for example, Figs. 1E; 3A, B, 5A, 8A-C, 9A), support local control by shale tectonics over slope depositional patterns (see Chima et al., 2019). The local increase in the CLS gradient down-dip of the in bile shale in Fig. 11B, the inversion of some normal faults during the Pleistocene (e.g. \& $\quad \therefore=\mathrm{Z}$ fault in Fig. 3B), and the presence of mud volcanoes on the modern seafloor (Figs. . F, 3A, B), further support movement of mobile shale on the western Niger Delta slope during "ie Pleistocene (see also Chima et al., 2019). These observations, therefore, call for $\mathrm{ca}^{\prime} \mathrm{t}^{-} \mathrm{n}$ r oncerning the widespread assumption that mobile shales in the Niger Delta were bu. ed during the late Pliocene (e.g. Cohen and McClay, 1996; Wiener et al., 2010; Morley et al., ?011).

\subsection{Depositional model}

Despite the dissimina smic facies association in MSU 1 and MSU 2 (e.g. Fig. 2B, C), the overall sedimentary architecture observed in the two units (Figs. 3-10), suggests that allogenic forcings at different scales and basin tectonics controlled the stratigraphic evolution of the western Niger Delta intraslope basins over the last 5.5 Ma. Comparing our observations in MSU 1 and MSU 2 (Figs. 2-10) with published depositional models (e.g. Posamentier and Kolla, 2003; De Gasperi and Catuneanu, 2014; Catuneanu, 2020), produced in a generalized facies association (Fig. 12) and a 3-dimensional depositional model (Fig. 13A-E) which explain the long-term stratigraphic evolution of the western Niger Delta slope over the last 5.5 Ma. 


\subsubsection{Falling stage}

Falling is controlled solely by episodes of relative sea-level falls and is the key criterion for the definition of stratigraphic cyclicity in deep-water settings (Posamentier and Kolla, 2003; De Gasperi and Catuneanu, 2014; Catuneanu, 2020). The highly incisional erosional surfaces we observed in MSU 1 and MSU 2 (e.g. Figs. 3, 5, 7, 8, 9A), which we interpreted as the falling stage erosional surfaces (FSESs; Fig. 12), were inferred to have u veloped respectively during the fourth- and fifth-order falling stage sea-level, erosion and 13A). While the basal MTDs, which locally overlie the FS. Ss (e.g. Fig. 5B), could represent the falling stage system tracts (Fig. 13A), high-density 8 ain/mud flows are inferred to have delivered sandy to muddy submarine fans to the L'sir floor (Catuneanu, 2020). The occurrence of basal MTDs at the bases of the erosion. ' $\mathrm{sr}^{\prime}$ smarine channels associated with horizons A and I (e.g. Figs. 3B, 4B, 5B, 7C, 8C), suggest that sediment-gravity flows were rich in mud and were partly sequestered in erosional surmat $n$; channels on the slope on their way to the deep basin (Fig. 13A). Similar observations have been reported in the deep-water eastern Niger Delta, where MTDs were calibrated with $\mathrm{c}^{-0}$ data and shown to be mud-rich (debris flows), linked to fourthorder relative sea-level $\mathrm{ta}{ }^{11}$ (see Zhang et al., 2019). The overall absence of MTDs at the bases of the erosional submarine channels in MSU 2, suggests that the former was eroded or not deposited in erosional submarine channels in this unit unlike in MSU 1 (compare Figs. 3A, B, 5B, 7C-E; 7C-E). Similarly, the paucity of MTDs in MSU 2 (e.g. Figs. 3A, B; 10A-C), could be related to overall changes in the sediment supply/calibre, the flow dynamics, or the relatively quiescent shale tectonics over the Pleistocene. 


\subsubsection{Lowstand}

The turbidite feeder channels/aggrading or meandering channel levee complexes (CLCs) are the most dominant seismic facies described in the two FSESs (Figs. 3-10). In the complex infilling of erosional submarine channels, the ubiquity of successive erosions and mass-flow deposits render interpretation more complex (e.g. Figs. 3B; 7C-E, 8C-E). The turbidite feeder channels/aggrading or meandering channel levee complexes (CLCs) and/or MTDs (slides/slumps) which generally infill the erosional submarine chaim ols in MSU 1 (e.g. Figs. 4B, 5B, 6B, 7C, 10B) and MSU 2 (e.g. Figs. 3A, B, 7C-E, 8C t, were inferred to have been developed during the lowstand/early transgression (see Caı neanu, 2020; Fig. 12B, C). Similarly, the regional MTDs previously interpreted to have bet. sourced from the upper slope/shelfmargin (see Chima et al., 2019; e.g. Figs. 3A, P; ${ }^{5} \mathrm{~B}$ 3C; 9B; 10A, B), were inferred here to be lowstand/early transgressive deposits (Fis $1^{2} \mathrm{~B}, \mathrm{C}$ ). The high amplitude reflectivity (HARS) of the turbidite feeder channels/aggradins or meandering channel levee complexes character, suggests that they were deposited f*n s. and-rich sediment-gravity flows (see also Chapin et al., 2002; Deptuck et al., 2003; Hei riö and Davies, 2007; Jobe et al., 2011; 2015). Although slope overstepping by normal and re ${ }^{*}$ sse faulting are known to trigger mass failures on the slope (e.g. Ricketts and Evenchick, 1yy9; Fatoke and Bhattacharya, 2010; Chima et al., 2019), the overall association of the regional MTDs with erosional events that correlate with relative sea-level lowering (e.g. horizon A in Fig. 3A, B; 10B, C), supports the interpretation of the former as lowstand deposits (see Posamentier and Kolla, 2003; De Gasperi and Catuneanu, 2014; Catuneanu, 2020). Low density turbidity currents and fine grain flows have been described as the main processes during the lowstand/early transgression (Catuneanu, 2020). Slope depositional 
patterns during the lowstand may have been locally influenced by the movement of mobile shales and associated fluid flows (see Riboulot $e$ t al., 2012; Figs. 1D; 3A, B; 8A, 9A, 13C).

\subsubsection{Transgression to Highstand}

The thick hemipelagic sediments that generally drape the entire system, where preserved (e.g. Figs. 3B, 7C-E, 8C-E), were inferred to have been deposited during the late transgressions/highstands, when the deep-water settings were stat ed of clastic sediment (see Posamentier and Kolla, 2003; De Gasperi and Catuneanu, 2014, ' Catuneanu, 2020; Fig. 13D). The conformable nature of the hemipelagic drape (e.g. F. rs. 3B, 7C-E, 8C-E), their mud-rich nature inferred from moderate gamma-ray $\log$ patterns (c . Fig. 13D) and their association with Discoaster qinqueramus as recorded in Well $3\left({ }^{\top} 3\right)$ (Fig. 13D), support their interpretation as transgressive/highstand deposits (see als. $C^{\prime}$.ima et al., 2019). Hemipelagic sedimentation is inferred to have punctuated deep-water c'position by shutting down sediment-gravity flows (see Burgess et al., 2008)

The foregoing processes were inferred to have occurred thirteen times in MSU 1 and eight times in MSU 2 (e. ${ }^{-} F_{i}$ 10B, C). A simplified schematic diagram illustrating the longterm $\left(4 / 5^{\text {th }}\right.$-order sea-lev ${ }^{1}$ controlled) incision, infilling and hemipelagic draping of submarine channels on the western Niger Delta slope is shown in Fig. 13E. Although the proposed model mainly hinges on long-term changes in relative sea level, our observations suggest that shale tectonics locally influenced depositional patterns on the western Niger Delta intraslope basins over the last 5.5 Ma.

\section{Conclusions}


Detailed seismic stratigraphy and 3D geomorphological analysis of high-resolution 3D seismic data over the Pliocene and Pleistocene stratigraphic record of the western Niger Delta intraslope basins, showed that:

1. Glacio-eustatic sea-level changes since the last $5.5 \mathrm{Ma}$ are recorded at regional scale in the intraslope basins of the western Niger Delta.

2. The depositional sequence in the intraslope basins of the west rn Niger Delta is generally defined by the falling stage erosional surface (FSES) at its has and top (sequence boundary), and is characterised by (i) basal MTDs/bypass facies ( "here preserved), (ii) turbidite feeder channels/aggrading or meandering channel levee a and (iii) hemipelagic drape that successively ' $\mathrm{e}$ ' esent the falling stage, lowstand to early transgressive, and late transgressive tc nig' stand systems tracts.

3. The Pliocene and Pleistocene stratig. aphy of the western Niger Delta intraslope basins was controlled by allocyclic forcir $1^{n 1}$.ed to glacio-eustatic sea-level oscillations and basin tectonics associated with mu bile shales, the latter being most active during the Pliocene and the middle Pleistocene

4. The overall higher adimentation rate over the MPT (0.8-1.0 Ma to present) possibly accompanied by subsidence was inferred to have facilitated the preservation of the $100 \mathrm{ka}$ sequences in MSU 2 compared to MSU 1 (5.5 to 0.8-1.0 Ma), where a slower sedimentation rate was inferred to have favoured the preservation of the 400 ka sequences.

5. This seismic stratigraphic study demonstrates for the first time sequence cyclicity associated with orbital (Milankovitch) forcing in the deep-water western Niger Delta and if calibrated 
with biostratigraphic data in future studies, could serve as a useful analogue for further studies in the Gulf of Guinea, the equatorial Atlantic and other margins fed by large deltas.

An ongoing study is investigating the control of delta top extensional tectonics over sediment sequestration/bypass on the shelf and its implication for gravity tectonics in the western Niger Delta.

\section{Acknowledgments}

We thank the Federal Republic of Nigeria for spor $\sim r_{1-}$ the $\mathrm{PhD}$ of Kelvin Ikenna Chima through the Petroleum Technology Development r . nd (PTDF) Scholarship Programme. We are grateful to Shell Nigeria not only for providing 'id data used in this study but also for permission to publish it. PTDF provided the ro` thanks to Schlumberger for providing Pe. ${ }^{-e}{ }^{(M)}$ software, which we used to interpret the data. The first author would like to thank he management and staff of Alex Ekwueme Federal University, Ndufu-Alike Ikwo, Ebr $\left.\sim v i{ }^{\star}\right\lrcorner t e$, Nigeria for their support and encouragement during this research. This study was ca-riea out at the Institut des Sciences de la Terre (ISTeP), Paris. An insightful discussion with Dalal U. Haq helped improve the quality of this paper. Zane R. Jobe is thanked for pro iding useful review comments on the first draft of the manuscript. Miguel-Mora Glukstad assisted in velocity modelling for time-depth conversion. Special thanks to Olusegun Obilaja, Adekemi Afolayan, Babatope Atitebi, Richard Streatfield and Timi Tralagba (Shell Nigeria) for their invaluable support with data. This paper benefited from the comments and suggestions of three anonymous reviewers. We thank the editor-in-chief (Liviu Matenco), for granting us sufficient time to revise this paper. 
Conflict of interest

I, Kelvin Ikenna Chima, wish to state clearly that I have dully acknowledged the donor of the dataset used in this study (Shell Nigeria) and also the sponsor, Petroleum Trust Development Fund (PTDF) of the Federal Republic Nigeria. I also wish to clearly state that there is no conflict of interest in this study.

\section{References}

Adeogba, A.A., McHargue, T.R., and Graham, S.A. 2005, Transient fan architecture and depositional controls from near-surface 3D seismic data, Niger Delta continental slope. AAPG Bulletin 89, 627-643.

Armitage, S.J., Bristow, C.S., Drake, N.A, 2015, West African mo: on dynamics inferred from abrupt fluctuations of Lake Mega-Chad. PNAS 112 (28),

Backman, J., Raffi, I., Rio, D., Fornaciari, E., Pälike, H., 201 ?, B ozonation and biochronology of Miocene through Pleistocene calcareous nanno 'ssis from low and middle latitudes. Newsl. Stratigr. 45, 221-244. https://doi.org/10. 1 $1<7 /$ 078-0421/2012/0022.

Bakare, O., Hurley, N., and McHargue, T., 2007, Fffact of Urowing Structures on Stratigraphic Evolution, Channel Architecture, and Su ra ine Fan Distribution, Niger Delta, West Africa. AAPG Conference Proceedin־ৎ, , alitornia.

Bassinot, F.C., Labeyrie, L.D., Vincent, E., ২ 'idelleur, X., Shackleton, N.J., and Lancelot, Y., 1994, The astronomical theory of climate and the age of the Brunhes-Matuyama magnetic reversal. Earth and Pia etaiy Science Letters 126, 91-108

Bellingham, P., Connors, C., Haw·rth, R., Barbara, R., Danforth, Al, 2014. The deep-water Niger delta: an underexp oreci world class petroleum province. Petrol. Geosci. Mag. $11,1-9$.

Benjamin, U. K., Hrus , N., and Hodgetts, D., 2015, Canyon-confined pockmarks on the western

Niger Delta slopa journal of African earth Sciences 107, 15-27.

Bilotti, F. D., Shaw, J. H., Cupich, R.M., and Lakings, R.M., 2005, Detachment fold, Niger Delta, in J. H. Shaw, C. Connors, and J. Suppe, eds., Seismic interpretation of contractional fault related folds: AAPG Studies in Geology 53, 103- 104.

Boulila, S., Galbrun, B., Miller, K. G., Pekar, S. F., Browning, V. B., Lasker, J., Wright, J. D., 2011., On the origin of Cenozoic and Mesozoic "third-order" eustatic sequences. EarthSciences Reviews (3-4), 94-112.

Burbank, D.W., 1992, Causes of recent Himalayan uplift deduced from deposited patterns in the Ganges basin. Nature, 357, 680-683.

Burgees, P. M., Steel, R. J. and Granjeon, D., 2008. Stratigraphic forward modeling of basin- 
margin clinoform systems: implications for controls on topset and shelf width and timing of formation of shelf-edge deltas. SEPM 90, 35-45.

Catuneanu, O., 2006, Principles of sequence stratigraphy. Elsevier, Amsterdam, 386.

Catuneanu, O., Galloway, W. E., Kendall, C. G. St. C., Miall, A. D., Posamentier, H. W., Strasser,

S., and Tucker, M. E., 2011, Sequence stratigraphy: Methodology and Nomenclature.

Newsletter on Stratigraphy, 44 (3), 173-245.

De Gasperi, A., Catuneanu, O., 2014. Sequence stratigraphy of the Eocene turbidite reservoirs in Albacora field, Campos Basin, offshore Brazil. Am. Assoc. Petrol. Geol. Bull. 98 (2), 279-313.

Catuneanu, O., 2020, Seqquence stratigraphy of deepwater systems. Marine and Petroleum Geology, 114 (104238). DOI: https://doi.org/10.1016/j.m arp tgeo.2020.104238

Chapin, M., Swinburn, P., van der Weiden, R., Skaloud, D., Ad sanya, S., Stevens, D., Varley, C., Wilkie, J., Brentjens, E., and Blaauw, M., ?.50\% Integrated seismic and subsurface characterization of Bonga Field, offshore Nigeria. "ne Leading Edge 21, 1125-113.

Chima, K. I., Do Couto D., Leroux, E., Gardin \& H jggmasacall, N., Rabineau, M., Granjean, D.,

and Gorini, C., 2019, Seismic s. 7 ti , raphy and depositional architecture of Neogene intraslope basins, offshore western 1 'iger Delta. Marine and Petroleum Geology 109, 449-468. doi: 10.1016/j.marpetge $、 2019.06 .030$

Chopra, S., and Marfurt, K.J., 2007, Se cr.lic attributes for prospect identification and reservoir characterization. Tulsa, O' 'ahoına, 457.

Clark, I. R. and Cartwright, I. A. 2012, Interactions between coeval sedimentations and deformation from tha 1 ireer Delta deep-water fold belt. SEPM 3, 243-267.

Clift, P.D., 2010, Enhanc -d global continental erosion and exhumation driven by Oligo-Miocene climate change. Fophys. Res. Lett., 37, L09402.

Cohen, H.A., and McClay, K., 1996, Sedimentation and shale tectonics of the northwestern Niger Delta front. Marine and Petroleum Geology 13, 313-328.

Collins, J.A., Schefuß, E., Govin, A., Mulitza, S., Tiedemann, R., 2014, Insolation and glacialinterglacial control on southwestern African Hydroclimate over the last 140,000 years. Earth and Planetary Science Letters 398, 1-10.

Connors, C. D., Denson, D. B., Kristiansen, G. and Angstadt, D. M., 1998, Compressive anticlines of the mid-outer slope, central Niger Delta (abs.) AAPG Bulletin, 82, 1903.

Corredor, F., Shaw, J.H., and Bilotti, F., 2005, Structural styles in the deep-water fold and 
thrust belts of the Niger Delta. AAPG Bulletin 89, 753780. https://doi.org/10.1306/02170504074

Crutchley, G.J., Klaeschen, D., Planert, L., Bialas, J., Berndt, C., Papenberg, C., Hensen, C., Hornbach, M., Krastel, S., Brueckmann, W., 2014, The impact of fluid advection on gas stability: investigation at sites on methane seepage, offshore Costa Rica. Earth and Planetry Science Letters 401, 95-109.

Damuth, J. E., 1994, Neogene gravity tectonics and depositional processes on the deep Niger Delta continental margin: Marine and Petroleum Geology, 11, 320-346.

Davies, R. J., 2003, Kilometer-scale fluidization structures formed during early burial of a deepwater slope channel on the Niger Delta. GSA 31 (11) 949-SJ?

Deptuck, M.E., Steffens, G.S., Barton, M., Pirmez, C., 2003. Ar nitc sture and evolution of upper

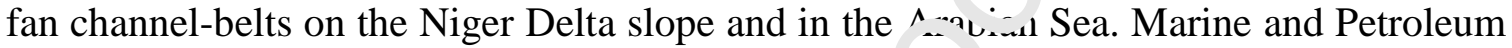
Geology 20, 649-676.

Deptuck, M.E., Sylvester, Z., O'Byrne, C., 2012, Iles'ocene seascape evolution above a "simple"

stepped slope-western Niger Delta, in: Pr «ar, B.E., Deptuck, M.E., Mohrig, D., Van Hoorn, B., Wynn, R.B. (Eds.), Application of the Principles of Seismic Geomorphology

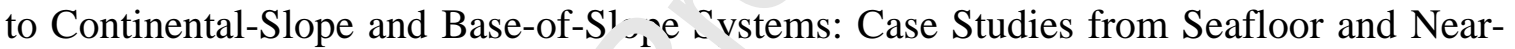
Seafloor Analogues, pp. 199-222.

Doust, H., and Omatsola, E., 1990, Nige, Delta, in J. D. Edwards and P. A. Santogrossi, (Eds.); Divergent passive margin basias 4 APG Bulletin 48, 239-248.

Einsele, G., Ricken, W., Seilacheı, A., i991, Cycles and Events in Stratigraphy. SpringerVerlag, Berlin, 955.

Eldefield, H., Ferretti, P., rrea ${ }^{\prime r}$ s, M., Crownhurst, S. J., McCave, I. N., Hodell, D. A., Piotrowski, A N, 2112 , Stable Oxygen isotope record and $\mathrm{Mg} / \mathrm{Ca}$ ratios at the MidPleistocene Cimate Transition, ODP Site 181-1123. Pangea. Doi: doi.org/10.1594,'D , NGAEA.786205.

Elliott, T.,1975, the sedimentary history of a delta lobe from a Yoredale (Carboniferous) cyclothem. Yorkshire Geological Society, Proceedings 40, 505-536.

Evamy, B.D., Haremboure, J., Kammerling, R., Knaap, W.A., Molloy, F.A., and Rowlands, P.H., 1978, Hydrocarbon habitat of Tertiary Niger Delta. AAPG Bulletin 62, 1-39.

Fatoke, O.A., Bhattacharya, J.P., 2010, Controls on Depositional Architecture and Sequence Stratigraphy of the Pliocene-Pleistocene Strata of Eastern Niger Delta, Nigeria. AAPG, Abstract, Denver.

Galloway, W. E., 2001, Cenozoic evolution of sediment accumulation in deltaic and shore-zone 
depositional systems, northern Gulf of Mexico Basin: Marine and Petroleum Geology, 18, 1031-1040.

Gibbard, P. L., Head, M. J, Walker, J. C., 2010, Formal ratification of the Quaternary System/Period and the Pleistocene Series/Epoch with a base at 2.58 Ma. Journal of Quaternary Science 25 (2), 96-102.

Gibbard, P. L., Head, M.J., and Walker, M.J., 2014, Subcomission on stratigraphy Formal ratification of the Quaternary System/Period and Pleistocene Series/Epoch with a base at 2.5 Ma. Quaternary Science 245, 96-102.

Gibbard, P.L., Lewin, J., 2016, Partitioning the Quaternary. Quate nary Science Reviews 151, 127-139.

Gorini, C., Haq, B.U., dos Reis, A.T., Silva, C.G., Cruz, A.M, Sı ares, E., and Grangeon, D., 2014, Late Neogene sequence stratigraphic evolution ni the Foz do Amazonas Basin, Brazil. Terra Nova, 26, (3), 179-185. https://doi.org/ 1 .1 11/ter.12083

Goudie, A. S., 2005, the drainage of Africa since the Cr stac 'ous. Gemorphology (3-4), 437-456.

Govin, A., Varma, V., Prange, M., 2014, Astronor: rainfall $\left(21^{\circ} \mathrm{N}-20^{\circ} \mathrm{S}\right)$ during the Last Interg ${ }^{\prime}$ ici il period. Geophysical research Letters 41 , 2117-2125. doi:10.1002/2013GL058,?9.

Gulick, S.P., Jaeger, J.M., Mix, A.C., Asahi, ' ' , Bahlburg, H., Belanger, C.L., Berbel, G.B., Childress, L., Cowan, E., Drab, L. Forwick, M., 2015, Mid-Pleistocene climate transition drives net mass loss from rap al, iplifting St. Elias Mountains, Alaska. Proc.Natl. Acad. Sci. Unit. States Am. 112, 1504?-15047.

Hansen, L., Janocko, M., Kane, . Kueller, B., 2017. Submarine channel evolution, terrace development, and prese ration of intra-channel thin-bedded turbidites: Mahin and Avon channels, offshore Nig $\sim *$ d. Mar. Geol. 383, 146-167. https://doi.org/10.1016/ j.margeo.2016 11. 111

Haq, B.U., Hardenbol, : Vail, P.R., 1987. Chronology of fluctuating sea levels since the triassic. Science 235, 1156-1167.

Head, M.J., Gibbard, P.L., 2015a, Early-Middle Pleistocene transitions: linking terrestrial and marine realms. Quat. Int. 389, 7-46. http://dx.doi.org/10.1016/j.quaint.2015.09.042

Head, M.J., Gibbard, P.L., 2015b, Formal subdivision of the Quaternary System/Period: past, present, and future. Quat. Int. 383, 1-32.

Heiniö, P., and Davies, R. J. 2007, Knickpoint migration in submarine channels in response to fold growth, western Niger Delta. Marine and Petroleum Geology 24, 434-449. doi.org/10.1016/j.marpetgeo.2006.09.002

Imbrie, J., Berger, A., Boyle, E.A., Clemens, S.C., Duffy, A., Howard, W.R., Kukla, G., 
Kutzbach, J.E., Martinson, D.G., McIntyre, A., Mix, A.C., Molfino, B., Morley, J.J., Peterson, L.C., Pisias, N.G., Prell, W.L., Raymo, M.E., Shackleton, N.J., and Toggweiler, J.R.,1993, On the structure and origin of major glaciation cycles 2. The 100,000-year cycle. Paleoceanography 8, 699-735.

Jermannaud, P., Rouby, D., Robin, C., Nalpas, T., Guillocheau, F., and Raillard, S., 2010, PlioPleistocene sequence stratigraphic architecture of the eastern Niger Delta: A record of eustasy and aridification of Africa. Marine and Petroleum Geology 27, 810-821.

Jervey, M.T.,1988, Quantitative geological modelling of siliclastic rock sequences and their seismic expressions. In: Wilgus, C.K., Hastings, B.S., St Kendall, C.G., Ross, C.A., Van Wagoner, J.C. (Eds.), Sea-level Changes: An Integrat zd Approach. SEPM Special Publication, Tulsa, 47-69.

Jobe, Z.R., Lowe, D. R., Uchytil, S.J., 2011, Two fundamenta"1" “.f.erent types of submarine canyons along the continental margin of Equator ${ }_{1}$ ? ( uinea. Marine and Petroleum Geology 28, 843-860.

Jobe, Z.R., Sylvester, Z., Parker, A.O., Howes, N., Slowe, N., Pirmez, and C., 2015, Rapid adjustment of submarine channel architect as to changes in sediment supply. Journal of Sedimentary Research 85, 729-753.

Jobe, Z.R., Sylvester, Z., Howes, N., Pirm ' '., '., Parker, A., Cantelli, A., Smith, R., Wolinsky, M.A., O'Byrne, C., and Slowey, N., 2016, High resolution, millennial-scale patterns of bed compensation on a sand-rici intraslope submarine fan, western Niger Delta slope. GSA Bulletin 129, 23-37.

Jolly, B.A., Lonergan, L., Whittah 'r, A.C., 2016. Growth history of fault-related folds and interaction with seabed , hanuels in the toe-thrust region of the deep-water Niger Delta. Mar. Pet. Geol. 70, 58-

Lafosse, M, Gorini, C L·Rc y, P., Alonso, B., D’Acremonta, E., Ercilla, G., Rabineau, M., Vázquez, J. T., ^ ’baute, R., Ammar, A., 2018, Late Pleistocene-Holocene history of a tectonically ac: 's segment of the continental margin (Nekor basin, Western Mediterranean, Morocco. Marine and Petroleum Geology 97, 370-389.

Leroux, E., Rabineau, M., Aslanian, D., Gorini, C., Droz, L. and Granjeon, D., 2014, Stratigraphic

simulation on the shelf of the Gulf of Lions: testing subsidence rates and sea-level curves during Pliocene and Quaternary. Terra Nova, 26, 230-238.

Leroy, S.A.G., Wrenn, J.H., Suc, J.P., 1999, Global setting to comparative charts of regional events. In: Wrenn, J.H., Suc, J.P., Leroy, S.A.G. (Eds.), The Pliocene: Time of Change. American Association of Stratigraphic Palynologist Foundation, 1-12.

Lisiecki, L.E., and Raymo, M.E., 2005, A Pliocene-Pleistocene stack of 57 globally distributed benthic $\delta{ }^{18}$ O records. Paleoceanography 20, PA1003. doi:10.1029/2004PA001071. 
Lisiecki, L.E., and Raymo, M.E., 2007, Plio-Pleistocene climate evolution: trends and transitions in glacial cycle dynamics. Quaternary Science Reviews 26, 46-69.

Lézine, A-M., Bassinot, F., Peterschmitt, J-Y., 2014, orbitally-induced changes of the Atlantic and

Indian monsoons over the past 20,000 years: New insights based on the comparison of continental and marine records

Madof, A.S., Christie-Blick, N., Anders, M.H., Febo, L.A., 2017, Unreciprocated sedimentation along a mud-dominated continental margin, Gulf of Mexico, U.S.A.: Implications for sequence stratigraphy in muddy settings devoid of deporitional sequences. Marine and Petroleum Geology 80, 492-516.

Miall, A.D., 2010, The Geology of Stratigraphic Sequences, s 522.

Miller, K.G., Kominz, M.A., Browning, J.V., Wright, J. D., ' Yountain, G.S., Katz, M.E., Sugarman, P.J., Cramer, B.S., Christie-Blick, N, . .d Pekar, S.F., 2005, The Phanerozoic Record of Global Sea Level Change. Scien _. Magazıne 310, 1293-1298.

Mitchum, R.M., and Vail, P.R., 1977, Seism:- S. atigraphy and Global Changes of Sea Level, Part 7: Seismic Stratigraphic Inter et cion Procedure: Seismic Stratigraphy: Applications to Hydrocarbon Exploration. AAPG N`moir 26, 135-143.

Morgan, R., 2004, Structural controls or the positioning of submarine channels on the lower slopes of the Niger Delta, in. [ a ies, R.J., Cartwright, J., Stewart, S.A., Underhill, J.R., Lappin, M. (Eds.), 3D Seismic Technology: Application to the Exploration of Sedimentary Basins. Ge 'ogical Society of London Memoir 29, 45-51

Molnar, P., 2004, Late C Cno $\sim$ c increase in accumulation rates of terrestrial sediment: how Might

Climate Change 1'vve Affected Erosion Rates? Annu. Rev. Earth Planet. Sci., 32, 67-89.

Morley, C. K., King, R., Hillis, R., Tingay, M., Backe, G., 2011, Deep-water fold and thrust belt classification, tectonics, structure and hydrocarbon prospectivity. Earth Sciences Reviews 104, 41-91.

Picot M., Marsset T., Droz L., Dennielou B., Baudin F., Hermoso M., De Rafelis M., Sionneau T.,

Cremer M., Laurent D., Bez M., 2019, Monsoon control on channel avulsions in the Late Quaternary Congo Fan. Quaternary Science Reviews, 204, 149-171.

Pälike, H., Frazier, J., Zachos, J.C., 2006. Extended orbitally forced palaeoclimatic records from the equatorial Atlantic Ceara Rise. Quaternary Science Reviews 25, 3138-3149. 
Posamentier, H.W., Jervey, M.T., and Vail, P.R., 1988, Eustatic controls on clastic deposition I. Conceptual framework. In: Wilgus, C.K., Hastings, B.S., Kendall, C.G.S.C., Posamentier, H.W., Ross, C.A., Van Wagoner, J.C. (Eds.), Sea-Level Changes-an Integrated Approach. SEPM Special Publication 42, 102-124.

Posamentier, H.W., and Kolla, V., 2003, Seismic geomorphology and stratigraphy of depositional elements in deep-water settings. Journal of sedimentary research 73, 367-388.

Prather, B.E., Booth, J.R., Steffens, G.S., Craig, P.A., 1998, Classification, Lithologic Calibration

and Stratigraphic Succession of Seismic Facies of Intraslope Basins, Deep- Water Gulf of Mexico. AAPG Bulletin 82 (5A), 701-728.

Prather, B.E., 2003, Controls on reservoir distribution, architecture $a^{-1}$ stratigraphic trapping in slope settings. Mar. Petrol. 20, 529-545

Prather, B.E., Pirmez, C., Sylvester, Z., and Prather, D. S., ’ 12 : tratigraphic Response to Evolving Geomorphology in a Submarine Apron Perched on the Upper Niger Delta Slope. SEPM 99, 145-161.

Pulham, A.J., 1989, Controls on internal structure .... ${ }^{\top}$ architecture of sandstone bodies within Upper Carboniferous fluvial-dominater elt Whateley, M.K.G., Pickering, K.T 'Eis.), Deltas: Sites and Traps for Fossil Flues. Geological Society, Special Public.tic ı, 41, 79-203.

Rabineau, M., Berné, S., Olivet, J-L., A.1anian, D., Joseph, P., and Guillocheau, F., 2006, Paleosea levels reconsidered $\mathrm{rC}^{-}$airect observation of paleo-shoreline position during Glacial Maxima (for the 1 nt in 000 yr). Earth and Planetary Science Letters, 252 (1-2), 119-137 DOI: 10.1C'6/j.cpsl.2006.09.033

Rabineau, M., Leroux, E., Aslaı ian, D., Bache, F., Gorini, C., Moulin, M., Molliex, S., Droz, L., Dos Reis, T., Drib. ${ }^{\circ}$, J-L., Olivet, J-L., 2014. Quantifying subsidence and Isostasy using paleoba`hyi netr \& markers : example from the Gulf of Lion, EPSL, vol. 388, p. 353- 366.

Raymo, M. E., Kozdon, R., Evans, D., Lorraine, E., Lisiecki, L., Ford, H. L., 2018, The accuracy of mid-Pliocene $\delta^{18} \mathrm{O}$ based ice volume and sea level reconstructions. Earth Science Reviews 177, 291-302.

Riboulot, V., Cattaneo, A., Lanfumey, V., Voisset, M., Cauquil, E., 2011, Morphological Signature of Fluid Flow Seepage in the Eastern Niger Submarine Delta (ENSD). Offshore Technology Conference.

Riboulot, V., Cattaneo, A., Berné, S., Schneider, R.R., Voisset, M., Imbert, P., Grimaud, S., 2012, Geometry and chronology of late Quaternary depositional sequences in the Eastern Niger Submarine Delta. Marine Geology, 319-322, 1-20.

Ricketts, B. D., Evenchick, C. D., 1999, Shelfbreak Gullies; Products of sea-level lowstands and 
sediment failure: Examples from Bowser Basin, Northern British Columbia. SEPM 69 (6), 1232-1240.

Ridente, D., Trincardi, F., Piva, A., Asioli, A., Cattaneo, A., 2008, Sedimentary response tol climate and sea level change during the past $\sim 400 \mathrm{kyr}$ from borehole PRAD1-2 (Adriatic Margin). Geochemistry, Geophysics, and Geosystems. 20 doi: http://dx.doi.org/10.1029/2007GC0017839/9Q09R04,

Rouby, D., Nalpas, T., Jermannaud, P., Robin, C., Guillocheau, F., and Raillard, S., 2011, Gravity driven deformation controlled by the migration of the delta front: The PlioPleistocene of the Eastern Niger Delta. Tectonophysics 513, 54-67. https://doi.org/10.1130/GEOSO1426.1

Ruddiman, W.F., Raymo, M.E., Martinson, D.G., Clement, B.M., àı ‘ Backman, J., 1989, Pleistocene evolution: northern hemisphere ice shee is and North Atlantic Ocean. Paleoceanography 4, 353-412.

Shackleton, N.J., 2000, The 100,000-year Ice-Age cycle ia ntified and found to lag temperature, carbon dioxide, and orbital eccentricity. Science 28;

Taner, M.T., Schuelke, J.S., O’Doherty, R., and Br y al, E.,1994, Seismic attributes revisited. In: SEG technical program expanded abstr، is 1994 . https://doi.org/10.1190/1.1822709. Thornton, S.E., 1984. Hemipelagiter : nu Associated Facies of Slopes and Slope Basins. In: Geological Society of London, 'ne ial Publications, 15, 377-394.

Tuttle, W.L.M, Brownfield, E.M., Charp. ntier, R.R., 1999, The Niger Delta Petroleum System Chapter A: Tertiary Niger D :'ta (Akata-Agbada) Petroleum System, Niger Delta Province, Nigeria, Camerorn a $\leadsto r$. Equatorial Guinea, Africa. USGS, Open File Report. 99-50-H, 4-44.

Weldeab, S., Frank, M., Sticheı, T., Haley, B., Sangen, M., 2011, Spatio-temporal evolution of the

West African mo isoc n during the last deglaciation. Geophysical Research Letters, 38, L13703. doi:10.1??y/2011g1047805.

Wiener, R.W., Mann, M. G., Angelich, M. T., and Molyneux, J. B., 2010, Mobile shale in the Niger Delta: Characteristics, structure, and evolution. AAPG, 93, 145-161.

Wu, N.N., Jackson, C. A-L., Johnson, H. D., Hodgson, D. M., Nugraha, H. D., 2020, Masstransport complexes (MTCs) document subsidence patterns in 1 a northern Gulf of Mexico salt minibasin. Basin Research, 1-28. DOI: 10.1111/bre.12429

Yoo, D-G., Kim, K-Y., Kang, N-K., Yi, B-Y., Cho, M-H., 2017, Plio-Quaternary seismic stratigraphy and depositional history of the Ulleung Basin, East Sea: Association with debris-flow activity. Quaternary International, 459, 69-88

Zecchin, M. 2007, The architectural variability of small-scale cycles in shelf and ramp clastic 
systems: the controlling factors. Earth-Sci. Rev., 84, 21-55.

Zecchin, M., Caffau, M., Tosi, L., Civile, D., Brancolini, G., Rizzetto, F., and Roda, C., 2010, The impact of Late Quaternary glacio-eustasy and tectonics on sequence development: evidence from uplifting and subsiding settings in Italy. Terra Nova 22, 324-329. doi: 10.1111/j.1365-3121.2010.00953.

Zecchin, M., Catuneanu, O. 2012, High-resolution sequence stratigraphy of clastic shelves I: units and bounding surfaces. Marine and Petroleum Geology 39, 1-25.

Zhang, J., Wu, S., Hu, G., Fan, T-E, Yu, B., Lin, P., Jiang, S., 2019, Sea-level control on the submarine fan architecture in a deep-water sequence of the Niger Delta Basin. Marine and Petroleum Geology 94, 179-197.
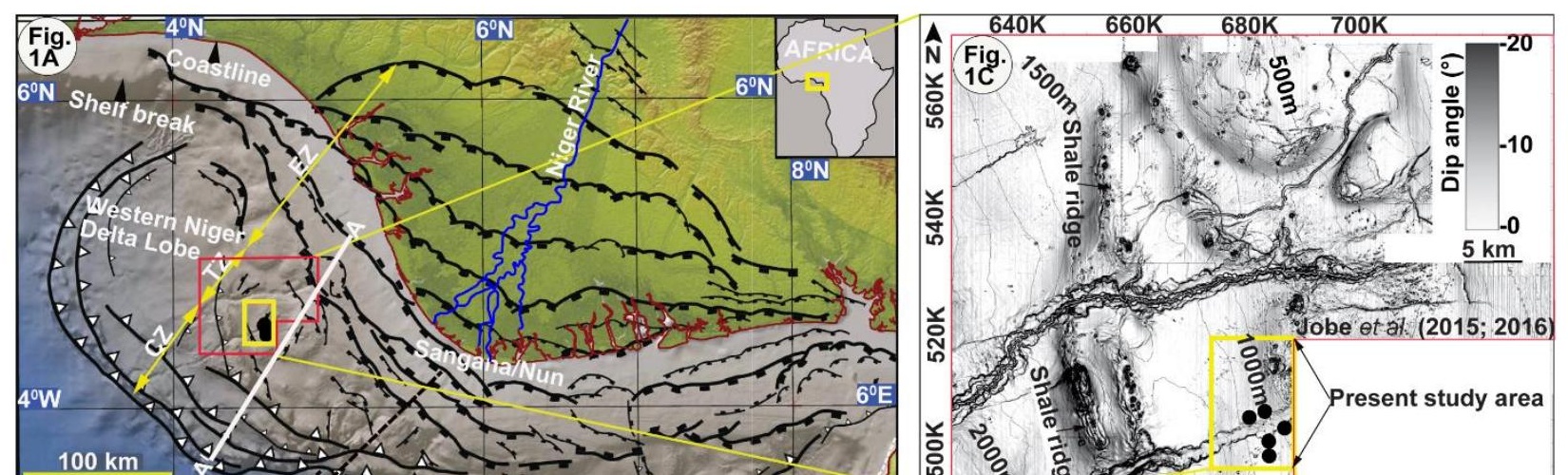
Fig. 1. Location of the study a $\cdot$ ea. A: superimposed relief and bathymetric map showing the extensional zone (EZ), tranclá ${ }^{+i}$,nal zone (TZ) and contractional zone (CZ) of the Niger Delta (adapted from Rouby $e_{\iota}$ zl., 2011). B: Seismic line drawing (AA ${ }^{\mathrm{I}}$ ) showing the styles of the structure (adapted from Bellingham et al., 2014). C: Dip in the seafloor showing the physiographic features of the translational zone (from Jobe et al., 2016). D: Depth structure map of the modern seafloor showing the presence of fluid flow features associated with mobile shales, mud volcanoes, pockmarks, and a mud-draped submarine channel in the study area (from Chima et al., 2019). Black circles in panels A, C (labelled W1-W5) in panel D indicate the locations of the wells. 


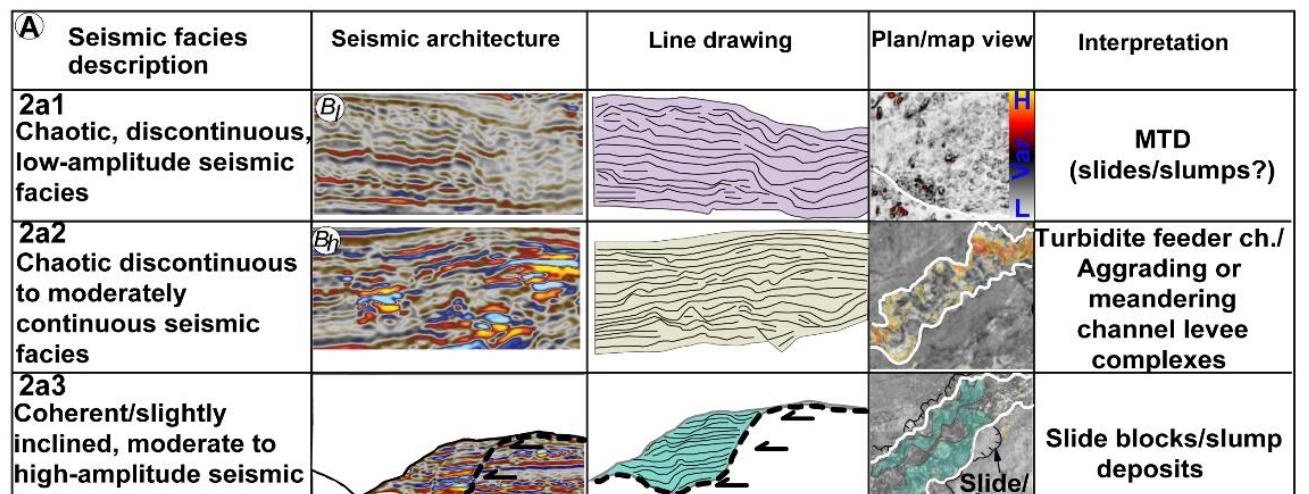


Fig. 2. A: Analysis of the seismic facies. A: Description and interpretation of the facies (modified from Chima et al., 2019). B, C: Association of the facies in and outside the erosional, submarine channels (see Figs. 3C and 5A for their location in panels B and C). See text for a more detailed explanation. 


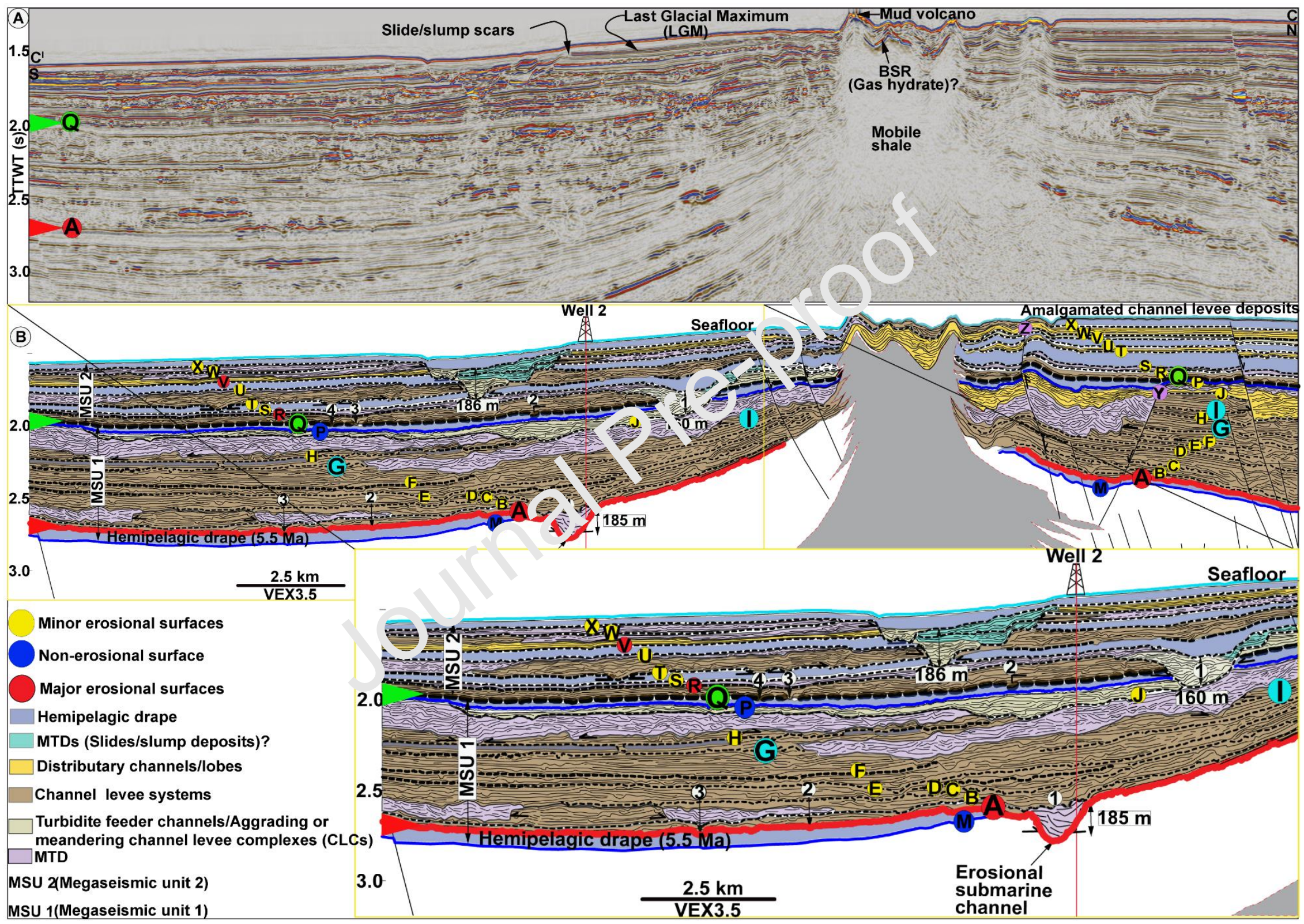



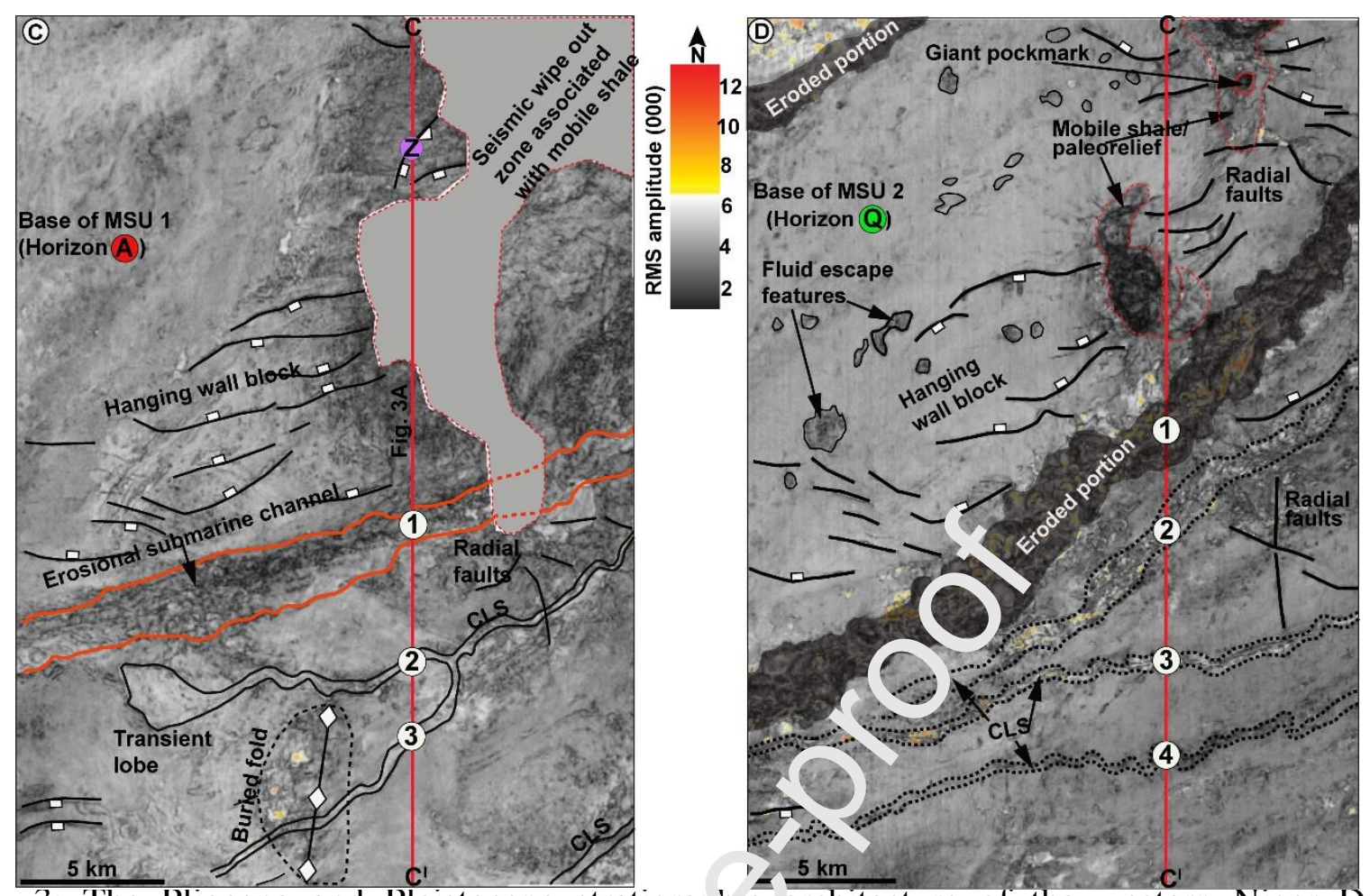

Fig. 3: The Pliocene and Pleistocene stratigras ic architecture of the western Niger Delta

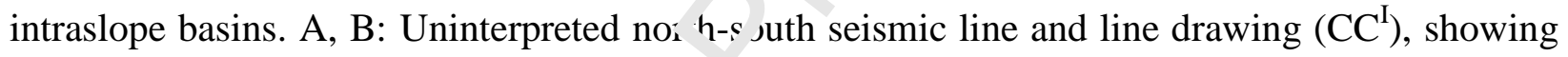
the depositional geometries of the MSL 1 and 2 (modified after Chima et al., 2019). Note the lateral thickening of stratigraphy ir the $\wedge_{S}$ SU 1 away from mobile shale. Yellow arrow points to the base of the hemipelagic a ve (horizon $\mathrm{M}$ ) dated at 5.5 Ma. Letters $(\mathrm{M}-\mathrm{X})$ in panel B represent seismic marker $N^{*}$ the changes in the sedimentary architecture from turbiditedominated at the lower ${ }_{r}$ art of the MSU 1 through a mix of MTDs and turbidites at the upper part of the MSU 1 to hemipelagic drape and turbidites at the transition between the MSU 1 and the MSU 2. Note the lateral truncations of seismic reflections within the MSU 1 compared to the MSU 2. Note also the occurrence of slide/slump scars below the modern seafloor (panel A) and the inverted fault (labelled $\mathrm{Z}$ in panel B). C, D: An interpreted RMS amplitude map of the horizons $\mathrm{A}$ and $\mathrm{P}$, draped on variance attribute extractions at the lower parts of the MSU 1 and 
the MSU 2, illustrating the changes in depositional elements. See text for a more detailed explanation. 


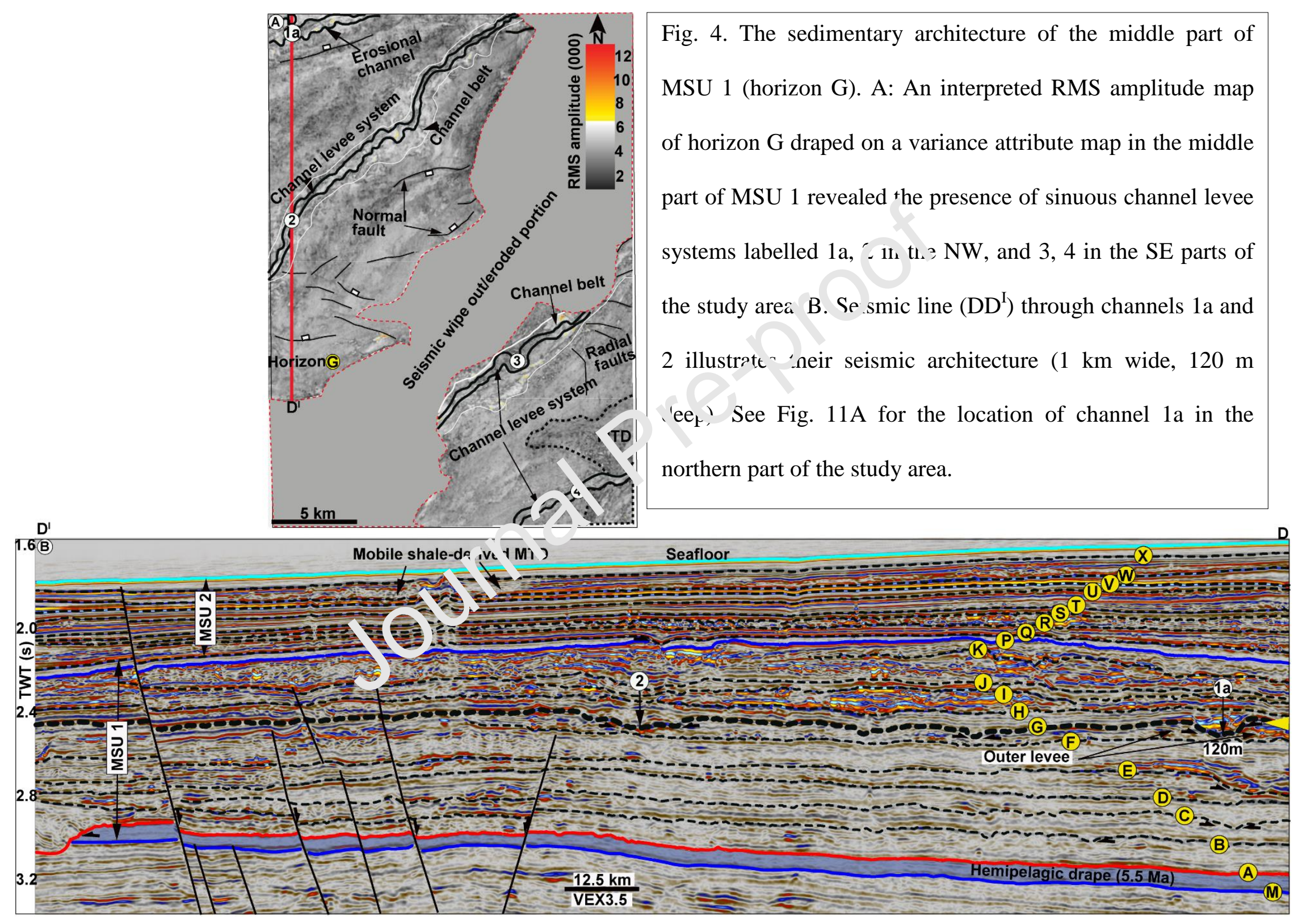



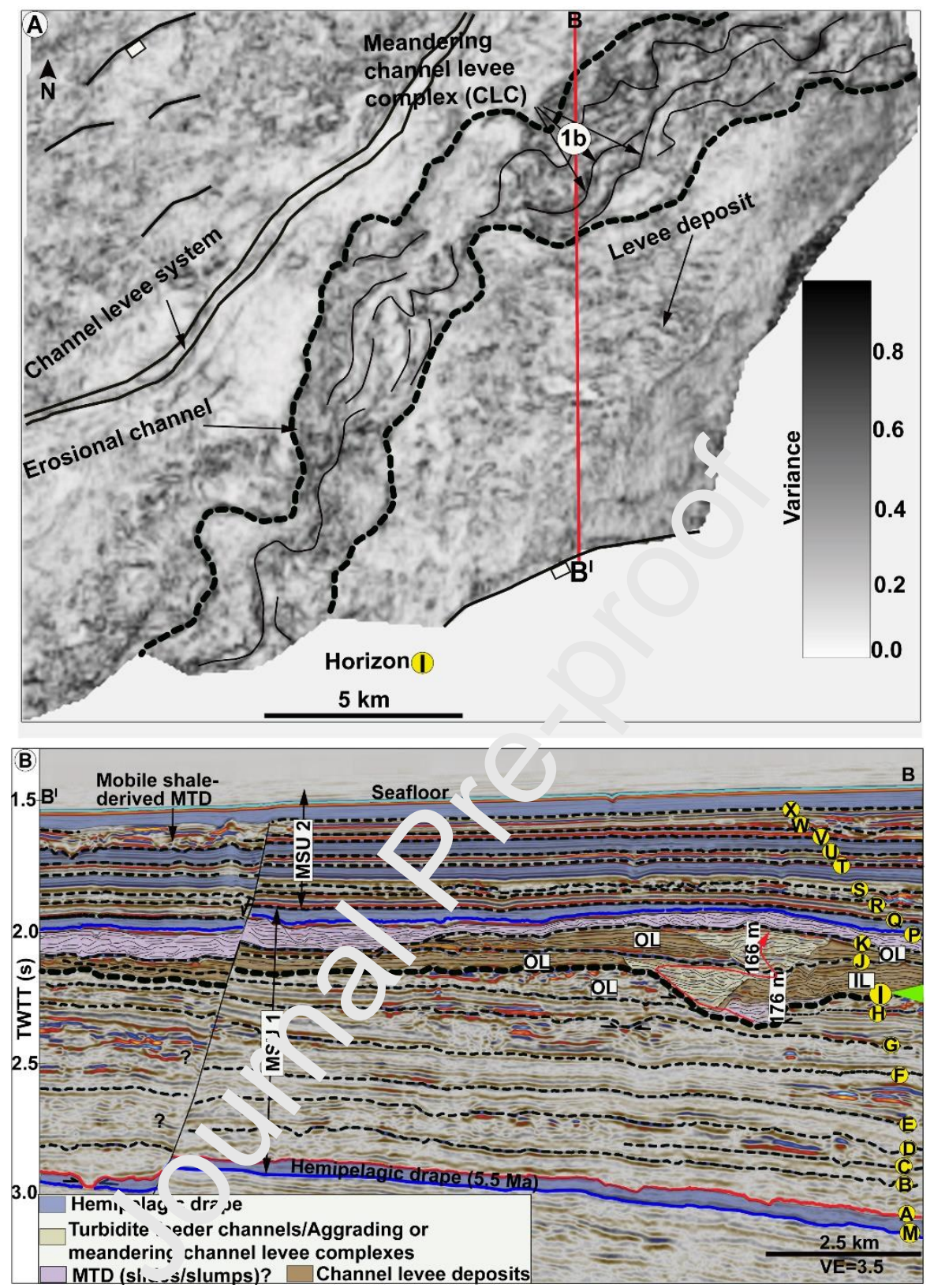

Fig. 5. The sedimentary architecture of the middle part of MSU 1 (horizon I). A: An interpreted variance attribute extraction on horizon I showing the presence of a $2.5 \mathrm{~km}$ wide sinuous, erosional channel, characterizsed by meandering CLCs and levee deposits (see yellow arrow in panel B for stratigraphic level). B: Seismic line $\left(\mathrm{EE}^{\mathrm{I}}\right)$ illustrates the complex cut and fill architecture (176 m deep) of the channel with lateral and vertical aggradational patterns. See Fig. $11 \mathrm{~A}$ for the location of channel $1 \mathrm{~b}$ in the northern part of the study area. 


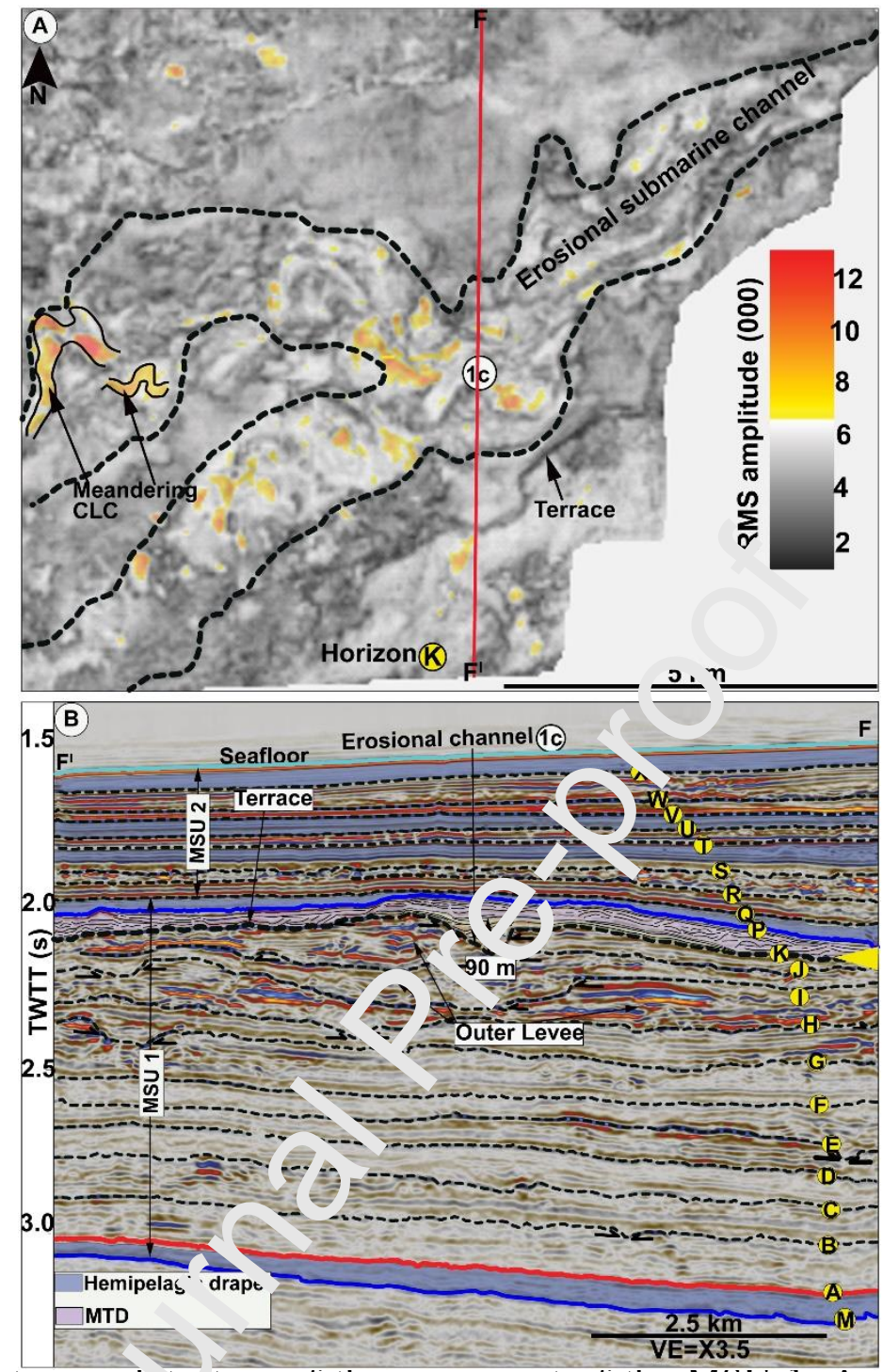

Fig. 6. The sedimentary ${ }^{m}$ n $_{1}$ - ture of the upper part of the MSU 1. A: An interpreted RMS amplitude map of horizu $\urcorner \mathrm{K}$, draped on a variance attribute map, shows the presence of a 1.8 km-wide bifurcating erosional channel, characterised by moderate RMS amplitude and terraces on its outer bend (see yellow arrow in panel B for the stratigraphic level). B: An interpreted north-south seismic line $\left(\mathrm{FF}^{\mathrm{I}}\right)$, shows the incisional character of the channel (90 m deep), infilled with partially confined, turbidite feeder channels/aggrading or meandering complexes that are truncated by the overlying MTDs (slides/slumps). See Fig. 11A for the location of erosional channel $1 \mathrm{c}$ in the northern part of the study area. 


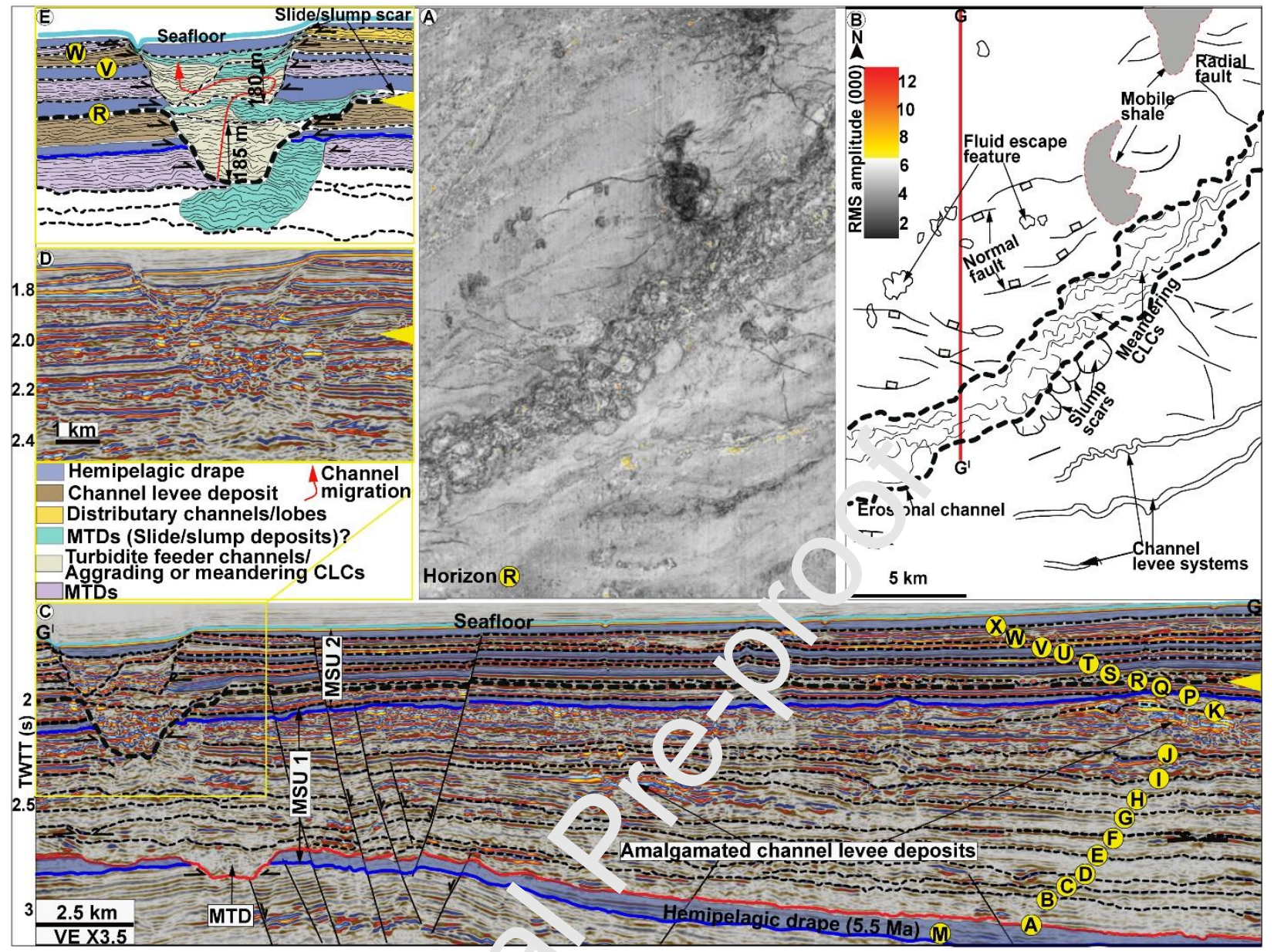

Fig. 7. The sedimentary architectum o: the middle part of MSU 2. A, B: An uninterpreted and interpreted RMS amplitude map of the horizon R draped on a variance attribute extraction shows the presence of a $2.5 \mathrm{~km}-\mathrm{x}^{\mathrm{r}} \mathrm{idt}{ }^{-1}$ annel, characterised by moderate RMS amplitudes and turbidite feeder channels/aggradiı ${ }_{i}{ }^{-}$or meandering channel levee complexes within the channel axis (see yellow arrow in panel $\mathrm{C}$ for the stratigraphic level). $\mathrm{C}$ : An interpreted north-south seismic line $\left(\mathrm{GG}^{\mathrm{I}}\right)$ illustrates the complex cut and fill architecture of the $185 \mathrm{~m}$-deep channel with overall vertical aggradational patterns (panels D, E). Note the upward decrease in the thickness of MTDs (slide/slumps?) and external levee deposits. See text for a more detailed explanation. 


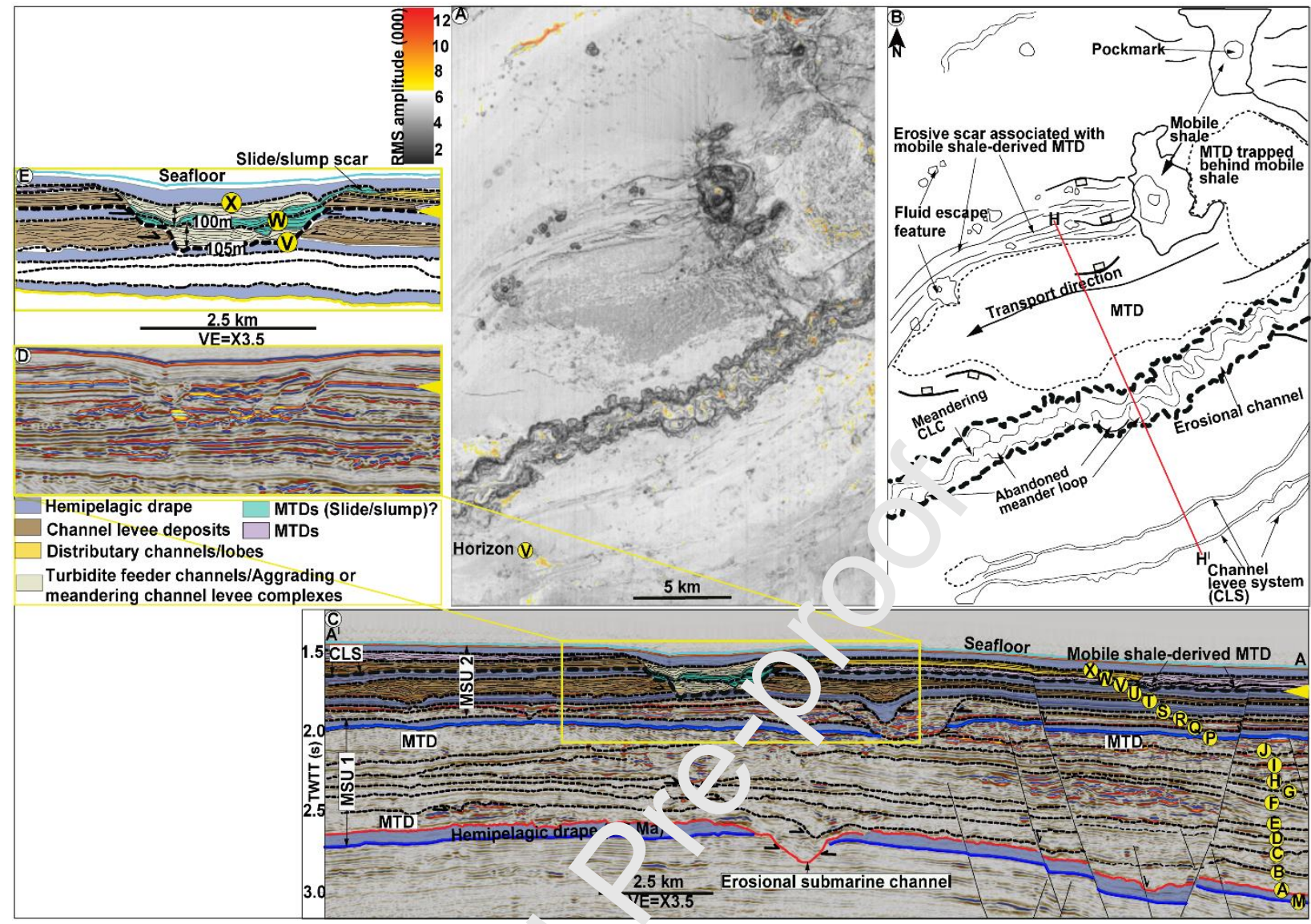

Fig. 8. The sedimentary architecture oi the upper part of MSU 2. A: An uninterpreted RMS

amplitude map of horizon $\mathrm{V}$ drape ${ }^{\lambda}$ or $\mathrm{v}$ ariance attribute map and $\mathrm{B}$ : an interpretation of panel

A,shows the presence of a 2.1 i $\mathrm{n}$-wide, sinuous erosional submarine channel, characterised by moderate amplitude and trohlcit ${ }^{i+}$ feeder channels/meandering CLCs (see yellow arrow in panel $\mathrm{C}$ for the stratigraphic level). Note the upward decrease in the thickness of the MTDs (slide/slumps?) and external levee deposits. C: An interpreted NW-SE seismic line $\left(\mathrm{HH}^{\mathrm{I}}\right)$ shows the complex cut and fill architecture of the channel (panels D, E). Note the upward decrease in the thickness of the MTDs (slide/slumps?) and external levee deposits. A, B, C (after Chima et al., 2019). 


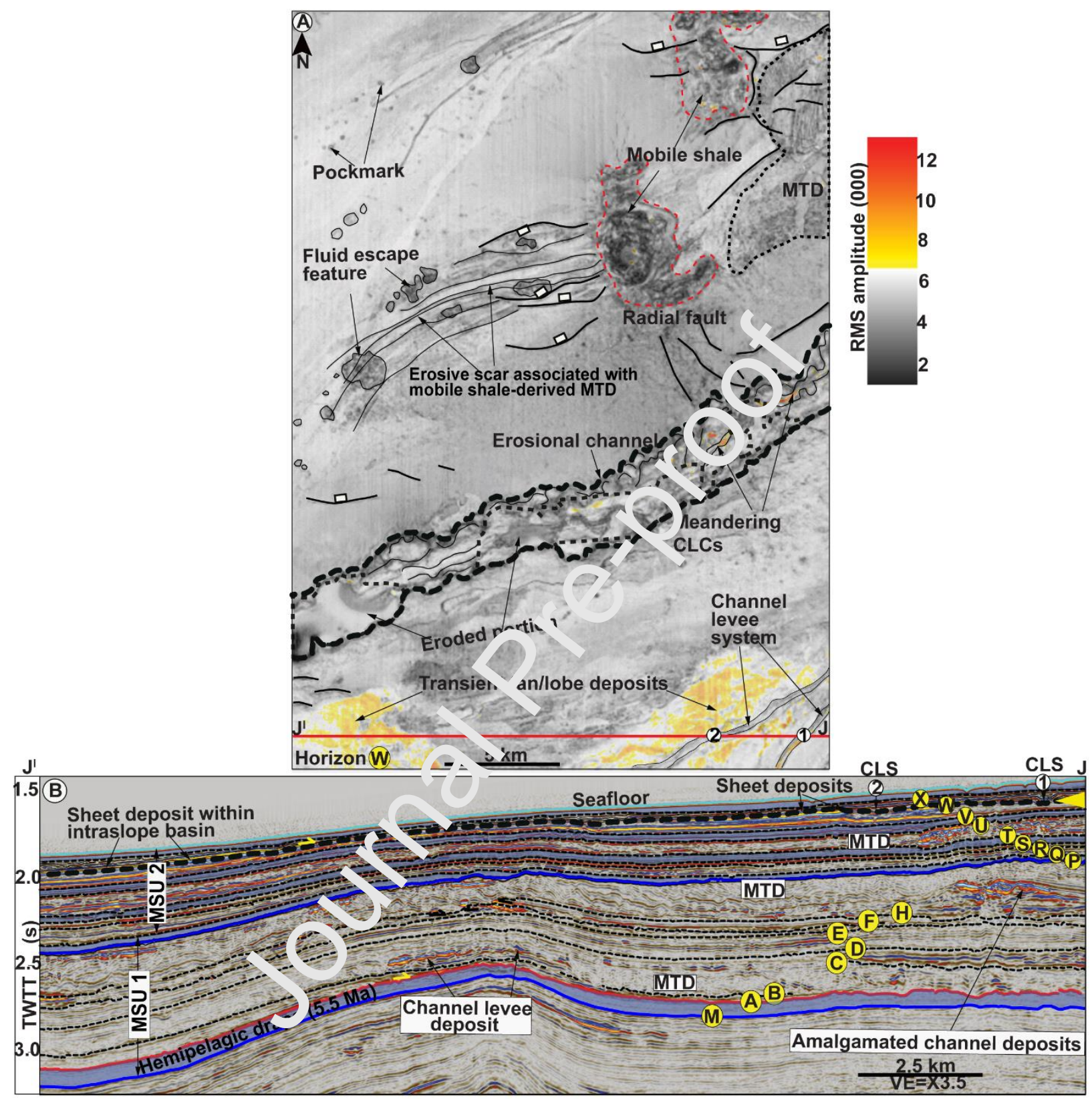

Fig. 9. Sedimentary architecture of the upper part of MSU 2. A: An interpreted RMS amplitude

map of horizon $\mathrm{W}$ draped on a variance attribute map shows the presence of MTDs trapped behind mobile shale in the north, a $2.5 \mathrm{~km}$ wide erosional channel in the central part of the study area and transient fan/lobes, marked by high RMS amplitudes in the south. B: An interpreted E- 
W seismic line $\left(\mathrm{JJ}^{\mathrm{I}}\right)$ illustrates the high reflectivity and onlapping geometry of the transient fans/lobes. Note the presence of mobile shales, mud volcanoes and pockmarks in panel A. 


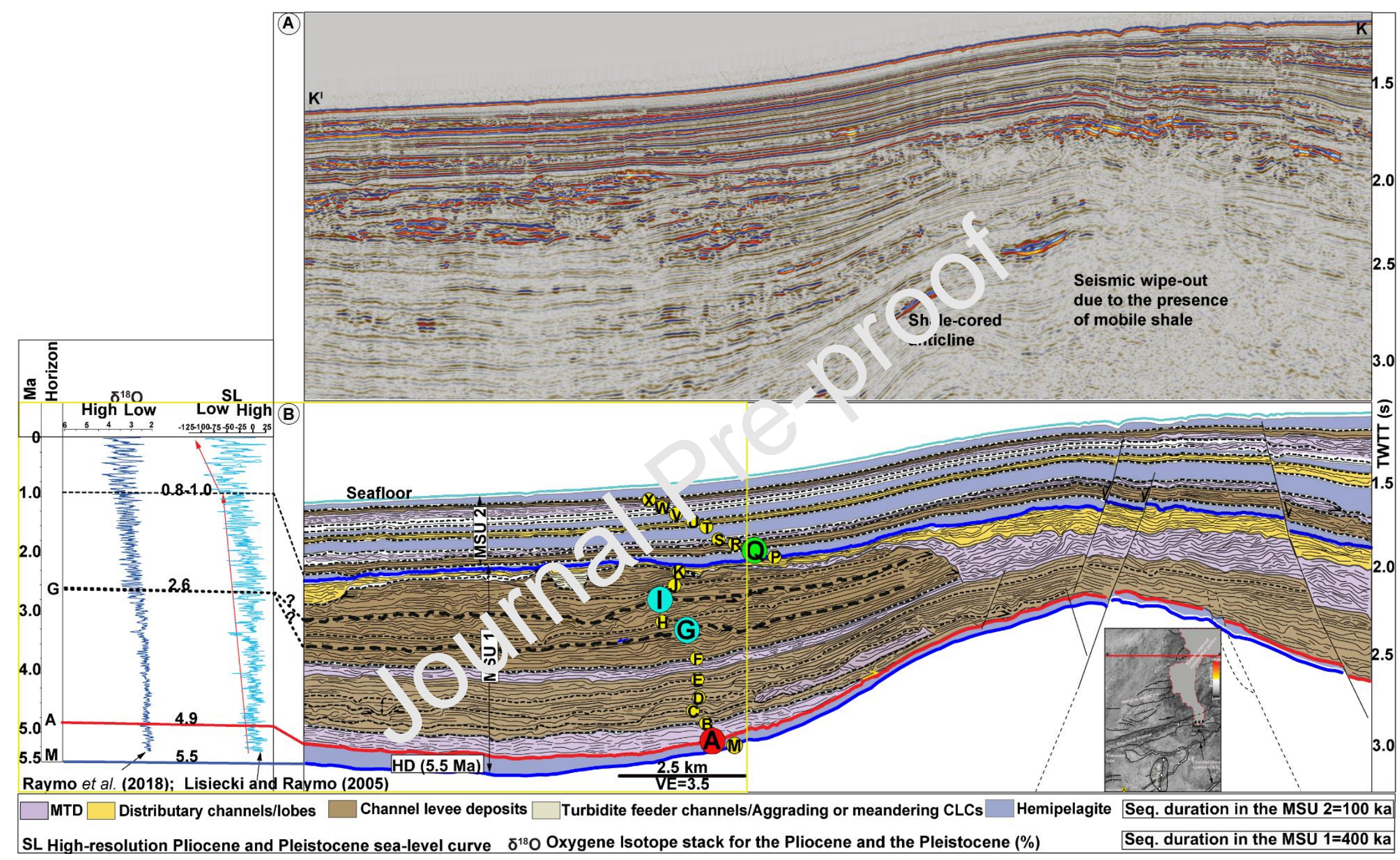




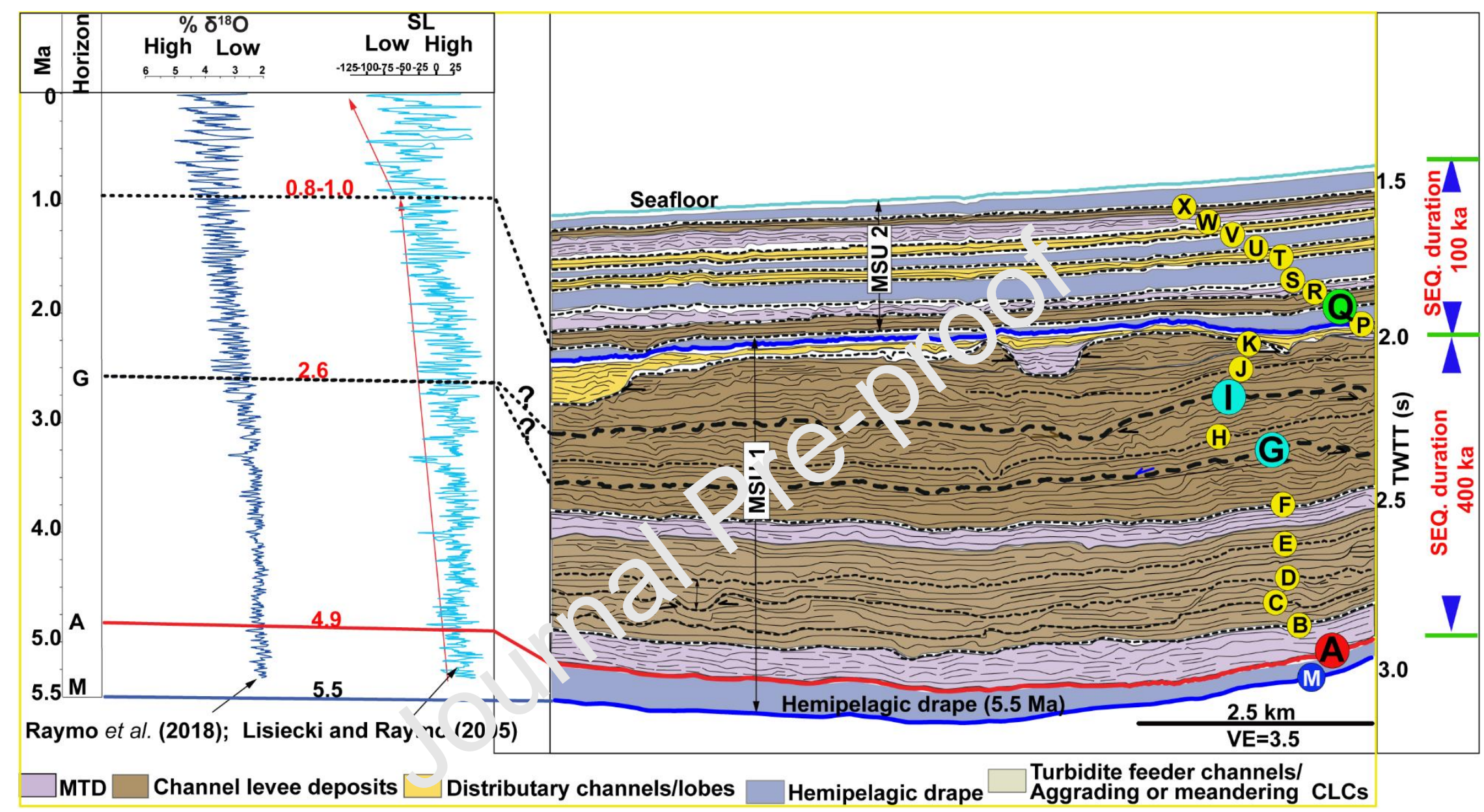

Fig. 10: Sequence stratigraphy. A: An uninterpreted and B: an interpreted E-W seismic and line drawing $\left(\mathrm{KK}^{\mathrm{I}}\right)$ shows the Pliocene and Pleistocene stratigraphic arichtecture of the western Niger Delta intraslope basins (see detailed view in panel C below). Note the tentative correlation between seismic markers at (the M/A, G/I and K/P) transitions with the sea-level and ${ }^{18} \mathrm{O}$ isotope curves. Note also the lateral variation in the stratigraphic thickness of MSU 2 compared to MSU 1. See text for a more detailed explanation. 


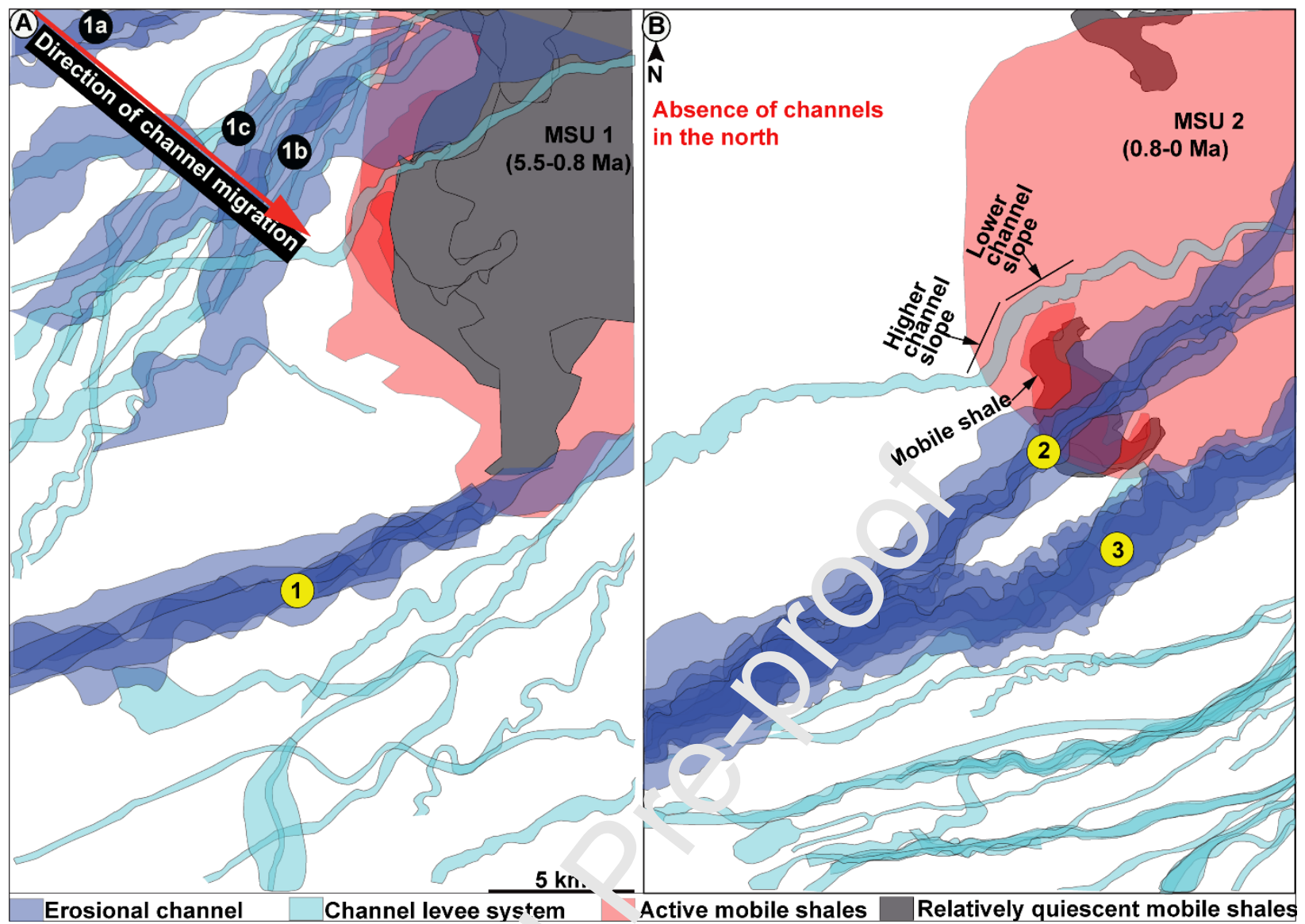

Fig. 11. Shale tectonics vs submarina chnnel morphology and distribution on the western Niger

Delta intraslope basins over the 'ast J.5 Ma. A: Migration of erosional channels from the NW to SE in (stages 1a-c in Figs 4-6). B: Absence of erosional channels in the northern part of the study area and an increas 1 in the slope of channel levee system (CLS) downdip of mobile shale. Note the space-time variation in the orientation of erosional channels in panels A and B (labelled 1, 2 and 3). A, B (modified after Chima et al., 2019). See text for a more detailed explanation. 


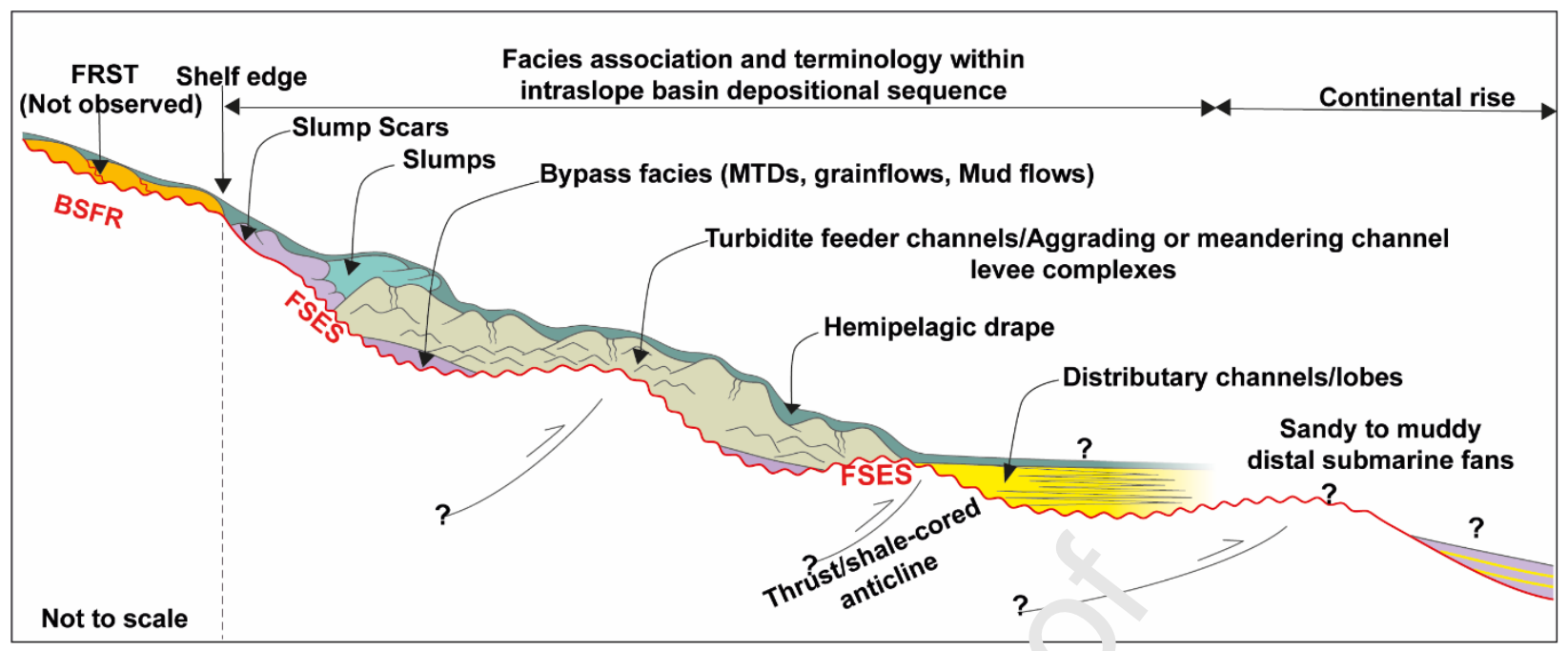

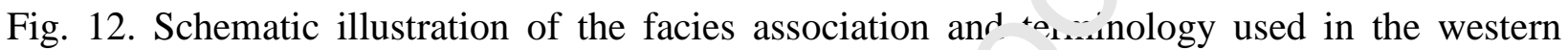

Niger Delta slope depositional model. The falling stage en 'sional surface (FSES) (this study) is equivalent to the basal surface of forced regressinn ,BSFR) defined on the shelf edge (Posamentier and Kolla, 2003; Catuneanu, 20? L. a Id corresponds to the erosional surfaces observed in MSU 1 and 2 (Figs. 3-1). The FSES is generally overlain by the basal MTDs/bypass facies (where preserved) (․ g. Fig. 5B). The turbidite feeder channels/aggrading or meandering channel levee compley $`$ a $\cdots$ the most abundant seismic facies defined between two FSESs and generally overlie th basal MTDs/bypass facies (where preserved; e.g. Fig. 5B) or directly overlie the FSESs (e.o Figs. 3B; 7C-E, 8C-E). The turbidite feeder channels/aggrading or meandering channc' levee complexes are generally overlain/truncated by MTDs (slides/slump?) deposits (e.g. Figs. 3B; 7C-E, 8C-E). The entire system is generally covered by hemipelagic drape/muddy turbidites where preserved (e.g. Figs. 3B; 7C-E, 8C-E). See section 5.3 for a more detailed explanation. 


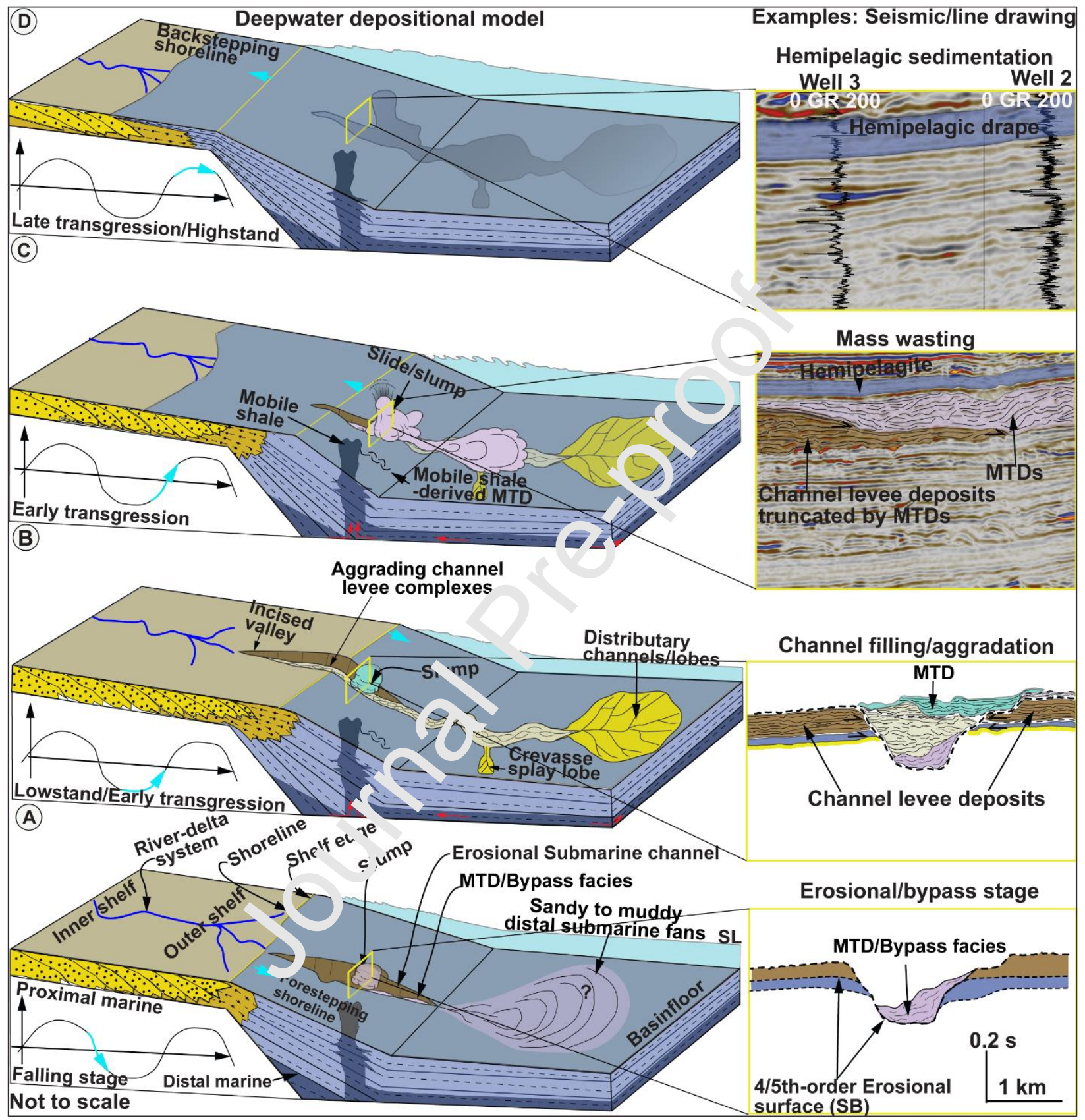

Fig. 13. Proposed depositional model illustrating the long-term Pliocene and Pleistocene stratigraphic evolution of the western Niger Delta intraslope basins with respect to fourth/fifthorder relative sea-level changes, locally influenced by shale tectonics. A: The falling stage marks the developemnt of erosional submarine channels/falling stage erosional surfaces (FSESs) and 
MTDs (bypass facies). B: The lowstand/early transgression marks the infilling/aggradation of erosional submarine channels C: Early/late trangression marks the onset of draping of submarine channels and the development of mass wasting that partially truncate the underlying lowstand deposits. D: The late trangressive/highstand stage marks the hemipelagic draping of erosional submarine channel complexes and the end of deepwater sedimention. Stages A-E are summarised in Fig. 13E.

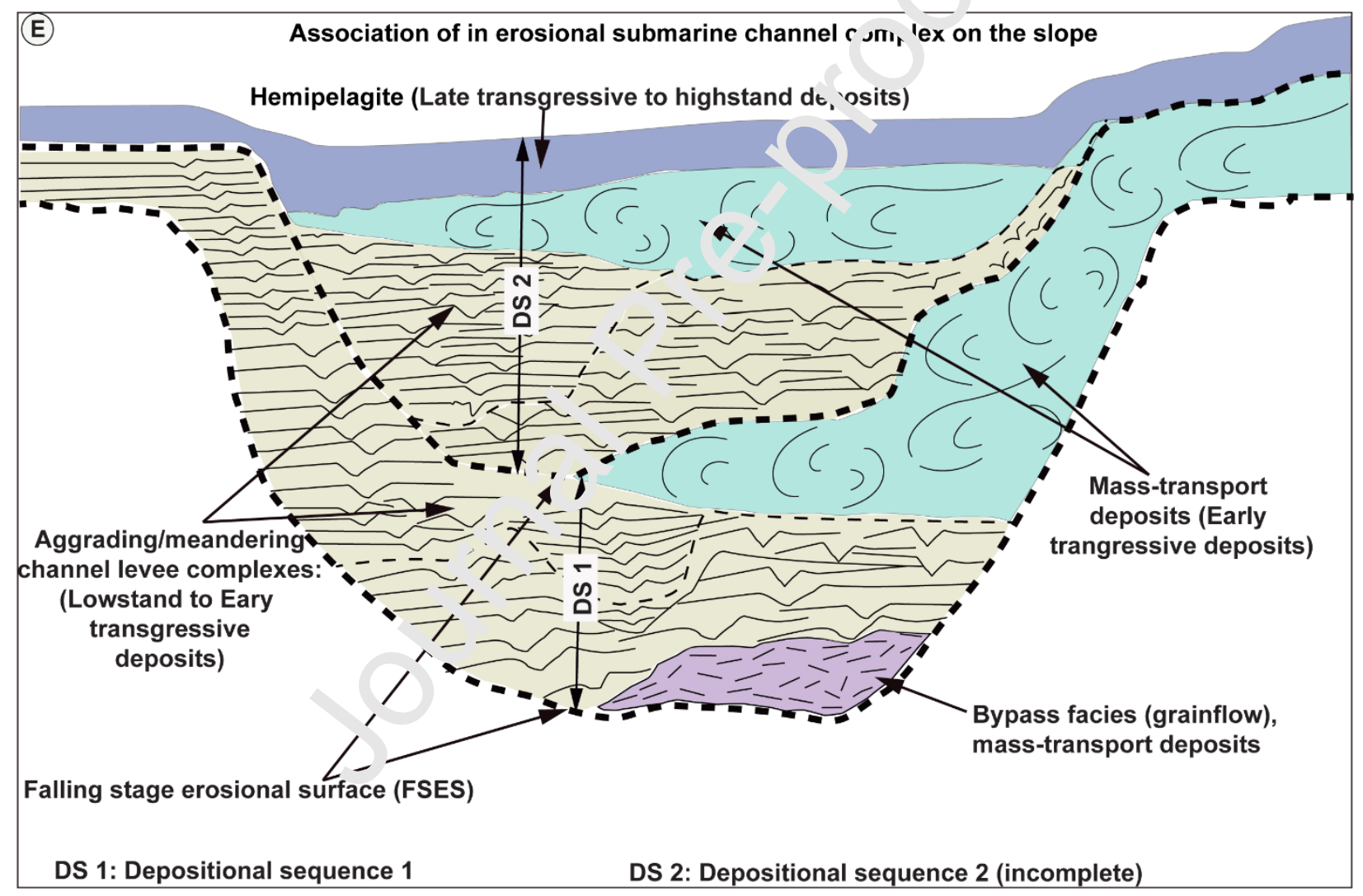

Fig. 13 E: Schematic illustration of facies association and systems tracts in the erosional submarine channel complex on the slope. 


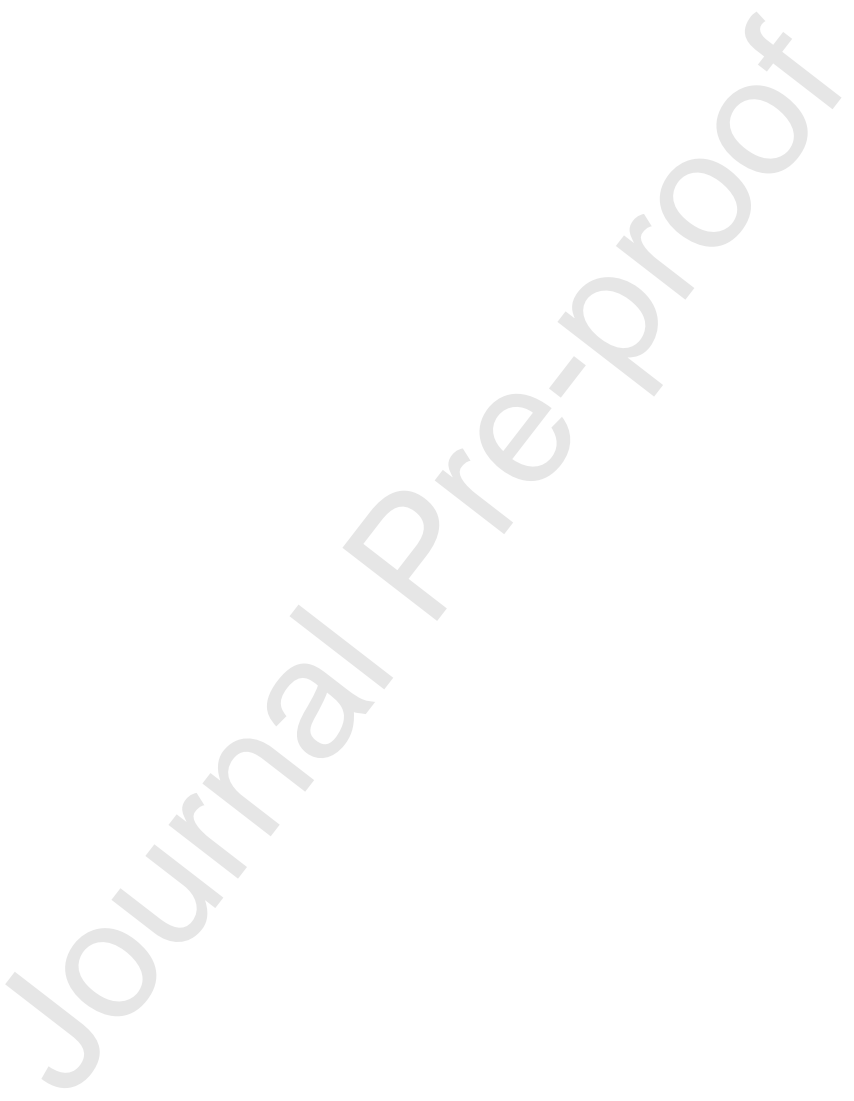


Highlights

- Seq. cycles linked to the Milankovitch cycles are recorded regionally on the Niger Delta slope

- The early Pliocene-mid Pleist. (5.5-0.8 Ma) is dominated by $400 \mathrm{ka}$ eccentricity sequences

- $\quad$ The mid Pleist.-present (0.8-0 Ma) is dominated by $100 \mathrm{ka}$ eccentricity sequences

- Increase in sedimentation rates at the MPT facilitated the preservation of the $100 \mathrm{ka}$ sequences.

- Glacio-eustatic and shale tectonic forcings controll a the Pliocene and Pleistocene stratigraphy 